\title{
Article
}

\section{New insights into the late Middle Stone Age occupation of Oued el Akarit, southern Tunisia}

\author{
R.N.E. Barton ${ }^{1}$, L. Belhouchet ${ }^{2}$, S.N. Collcutt ${ }^{3}$, N. Aouadi ${ }^{4}$, P.G. Albert ${ }^{5}$, K. Douka ${ }^{6}$, N. Drake ${ }^{7}$, L. Linderholm ${ }^{8}$, \\ R.I. Macphail ${ }^{9}$, D. McLean ${ }^{10}$, H. Mekki ${ }^{11}$, D. Peat ${ }^{12}$, J.-L. Schwenninger ${ }^{13}$ and V.C. Smith ${ }^{14}$ \\ ${ }^{1}$ University of Oxford, UK; ${ }^{2}$ Institut National du Patrimoine, Tunisia; ${ }^{3}$ Independent Researcher, Oxford, UK; ${ }^{4}$ Institut National du Patrimoine, Tunisia; ${ }^{5}$ Swansea \\ University, UK; ${ }^{6}$ Max Planck Institute for the Science of Human History, Germany; ${ }^{7}$ King's College London, UK; ${ }^{8}$ University of Umeå, Sweden; ${ }^{9}$ University College London, \\ UK; ${ }^{10}$ University of Oxford, UK; ${ }^{11}$ Institut National du Patrimoine, Tunisia; ${ }^{12}$ University of Oxford, UK; ${ }^{13}$ University of Oxford, UK and ${ }^{14}$ University of Oxford, UK
}

\section{Abstract}

This article reports on a new project to investigate the activities of early Homo sapiens in the area of the Chotts 'megalake' in southern Tunisia. Excavations in 2015 and 2019 at Oued el Akarit revealed one of a number of Middle Stone Age (MSA) horizons near the top of a long sequence of Upper Pleistocene deposits. The site identified as Oued el Akarit (Sondage 8) consists of lithic artefacts, bone fragments of large ungulates and pieces of ostrich eggshell. Many of the objects are burnt. Excavation of about nine square metres revealed that these were associated with a lightly trampled and combusted occupation surface. Amongst the identified artefacts were Levallois flakes some of which could be refitted, thereby indicating the generally undisturbed nature of the occupation. The lithic finds also included side scrapers and other tools diagnostic of the MSA but significantly no bifacial or tanged tools. OSL (Optically Stimulated Luminescence) dating of the sediments and AMS (Accelerator Mass Spectrometry) radiocarbon dating of ostrich eggshell have produced uncalibrated age determinations in the range 37,000-40,000 years ago, one of the youngest ages for MSA sites in the region. This is the first example of a securely dated later MSA occupation in a riparian environment in south-eastern Tunisia.

$$
\text { نيك بارتون وآخرون. للاستيطان البشري في أواخر العصر الحجري الوسيط لوادي العكاريت، جنوب تونس }
$$

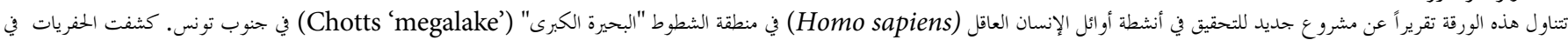

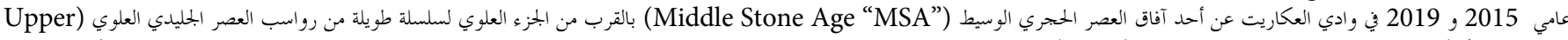

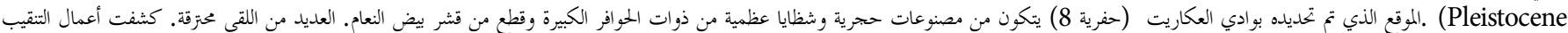

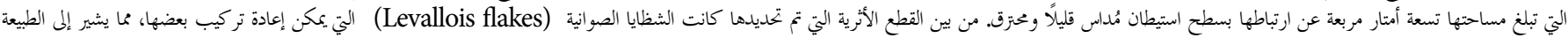

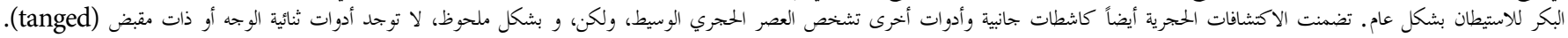

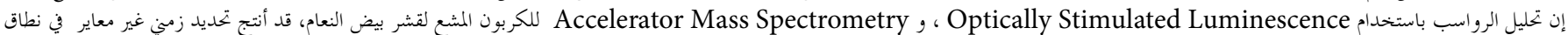

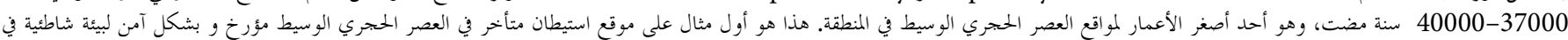

\section{Introduction and background}

Tunisia is a key region for understanding the nature and dispersal of early African humans (Homo sapiens) in the period 300,000 to 10,000 years ago (Drake et al. 2011; Coulthard et al. 2013). A focus of special interest is a ribbon of former lake basins known as the Chotts which runs through southern Tunisia and Algeria on the northern edge of the Sahara, occupying a very large surface catchment area of some $814,000 \mathrm{~km}^{2}$. Today, the Chotts form an inhospitable 'barrier' of extensive saline mudflats but the presence of freshwater mollusc species on former lake shorelines suggests past conditions were much more favourable for humans and other animals (Causse et al. 2003). At its fullest extent, the basin would have formed a 'megalake' fed by local springs and small rivers emanating from the Atlas Mountains and by major river systems that have their sources in the Tassili n-Ajjer and

Corresponding author: R.N.E. Barton, Email: nick.barton@arch.ox.ac.uk

Cite this article: Barton RNE et al (2021). New insights into the late Middle Stone Age occupation of Oued el Akarit, southern Tunisia. Libyan Studies 52, 12-35. https://doi.org/ 10.1017/lis.2021.9
Hoggar Mountains of the central Sahara (Figure 1). It was in proximity to these peripheral streams and springs, whether just above or below the contemporary shoreline (groundwater baseline), that salinity would have been at its lowest and the surface water, in many places, potable. Such factors would of course have been particularly important in influencing the distribution of humans in the landscape and in determining the extent to which the Chotts occupied a strategic position for populations migrating north of the Sahara. However, despite the immense potential relatively little is known about the early prehistoric occupation of this region of North Africa.

A new project to survey and investigate the Middle Stone Age (MSA) and Later Stone Age (LSA) occupation in southern Tunisia was initiated by the University of Oxford and the Institut National du Patrimoine de Tunisie in 2013 and a first season of field survey took place in 2014. The aims of the project were to map, identify and undertake small scale excavation and sampling of known and newly discovered MSA and LSA sites in the area of the former Chotts megalake and related drainage basins (Figure 1). The overall objective was to collect 


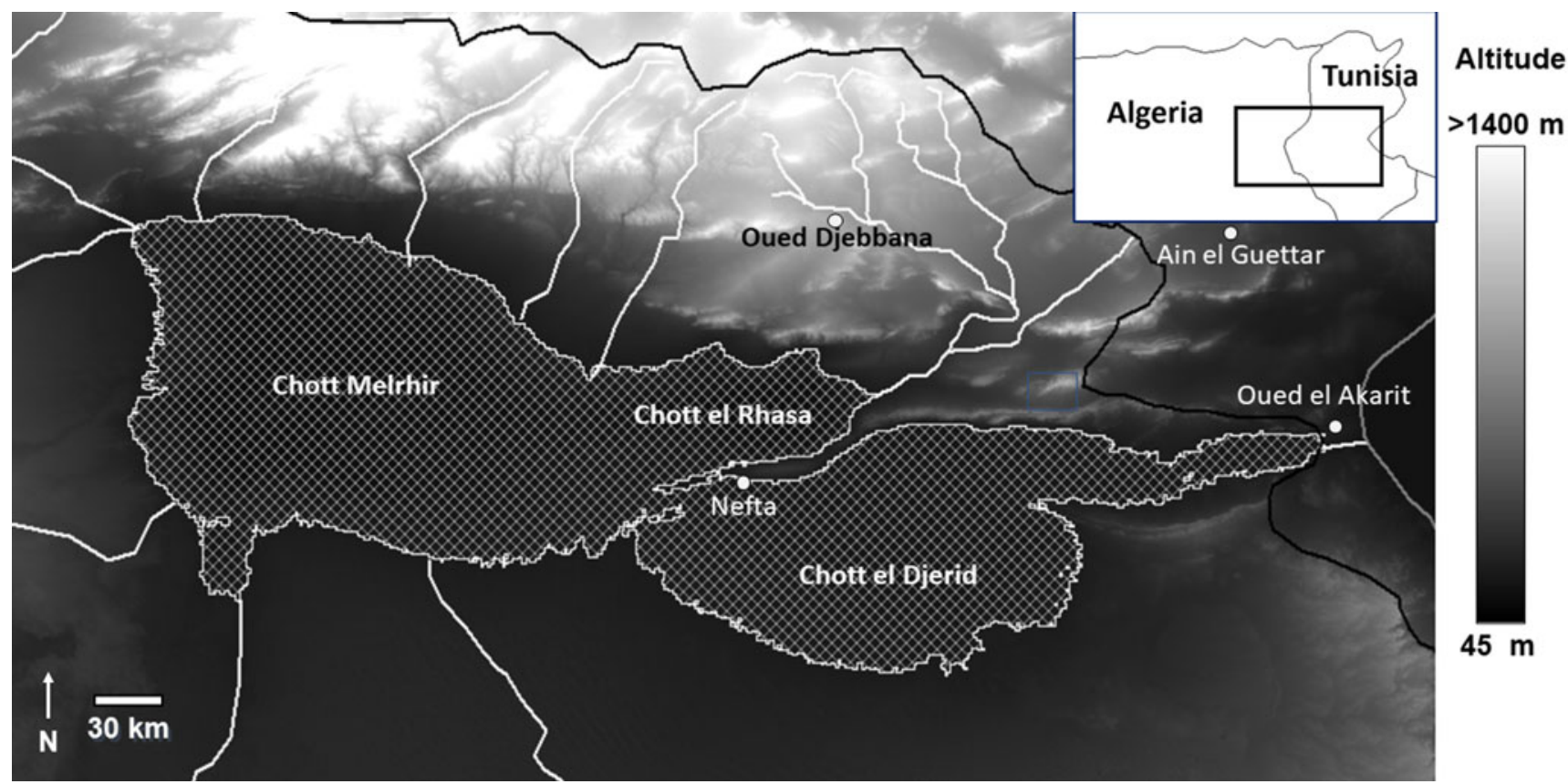

Figure 1. Map of Akarit and other sites mentioned in the text in relation to the Chotts 'megalake'. The thin white line shows the putative shoreline of the megalake at its maximum, the black line shows the boundary of its catchment and the thick white lines indicate rivers that flowed into the lake ( $\mathrm{N}$. Drake).

chronological, environmental and cultural evidence that would allow clearer understanding of the nature and periodicity of human occupation in southern Tunisia close to the present northern edge of the Sahara. Oued el Akarit was amongst several locations selected for survey, as it presented a significant clustering of springs, potentially forming part of a natural corridor for wildlife and human populations in between the Sahara and the Mediterranean Sea. During more arid phases, the springs would have offered freshwater, riparian vegetation and aquatic resources, and may have formed 'oases' of human and animal activities in their own right.

\section{The site and its context}

Oued el Akarit has been known for its high density of archaeological sites since the 1930s (Gobert 1962; Gobert and Howe 1955; Roset and Harbi-Riahi 2007). The main point of interest is an area of exposed Upper Pleistocene age deposits in the lower part of the oued (Figure 2), close to where the GP1 highway and railway line cross the wadi near the village of El Akarit. It lies about 25 $\mathrm{km}$ north of the provincial capital of Gabès in southern Tunisia.

\section{Structural geology and sedimentological setting}

Presented here is a summary of observations relating to the local geology. A more detailed discussion of the Quaternary structural geology of Oued el Akarit will appear in a future publication. The present oued flows southeastwards and then eastwards before reaching the sea at approximately the mid-point of the Gulf of Gabès embayment. The modern catchment is relatively small, with various authors giving estimates in the range ca. $75-110 \mathrm{~km}^{2}$; the west-east extent of the modern catchment is only $17 \mathrm{~km}$. During occasional torrential rainfall events, there is potential for considerable geomorphological remodelling but in this arid to semi-arid area, there would probably have been very little, if any, surface water availability during much of the Upper Pleistocene and Holocene - indeed, the upper and middle reaches of the catchment are normally dry today. However, the oued runs through the El Meïda Graben ${ }^{1}$ between two zones of fault-bound highlands. Crossing the hard-rock basement of this graben somewhat obliquely, there is at least one major fault zone that is able to tap into artesian waters, with very slow (>20,000 years) turnover times, originating from the mountains to the north of the Chotts. Published hydrographic studies in the area have suggested that the piezometric head ${ }^{2}$ is several metres above the general land-surface (despite the water table being radically lowered by agricultural and industrial pumping), the potential for springs being limited only by the extremely low transmissivity within the deep fault system. There is therefore reason to believe that, whilst springs would have been located in the topographic low-points available at any given time, the actual altitude of these low-points would not have mattered greatly during the timescale of interest here, suggesting that water at the surface would have been available in this vicinity more or less continuously, irrespective of the point (altitude) in any given sedimentary cycle (see below).

In the lower reaches of the modern oued (after the confluence with a main northern tributary and in the zone most affected by the deep artesian seepage, the last $5 \mathrm{~km}$ before the modern coast), the general surface lies at an altitude of some $25 \mathrm{~m}$ above mean sea level, dropping towards the east; it is only from this point that there has been strong incision, creating a 'gorge', now as much as $40 \mathrm{~m}$ wide at the base (potential floodplain) and rarely more than $80 \mathrm{~m}$ wide at the top, and up to $15 \mathrm{~m}$ deep in places. The present 'gorge' is wholly Holocene in age. The gorge downcutting has exposed stacks of much older sediments (usually dominated by material in the coarse silt to fine sand grades), each accretive cycle (representing sequences of ca. 10-20,000 years in stacks of exposed thicknesses in the range ca. 5 to $15+\mathrm{m}$ ) separated by incision events, the unconformities bounding previous 'valleys/gorges', not necessarily following exactly the modern thalweg. ${ }^{3}$ There is therefore great archaeological and palaeontological potential in these normally very well stratified sequences. However, there is also considerable structural complexity, because these weakly consolidated/cemented sediments have responded again and again to localised faulting, slippage, rotation, plastic deformation and mass movement, whenever an incision event has produced significantly steepened 'gorge-sides'. This instability is exacerbated by the continual presence of basal artesian input. This complexity has tended to mislead many researchers in the past, who have envisaged incorrect 


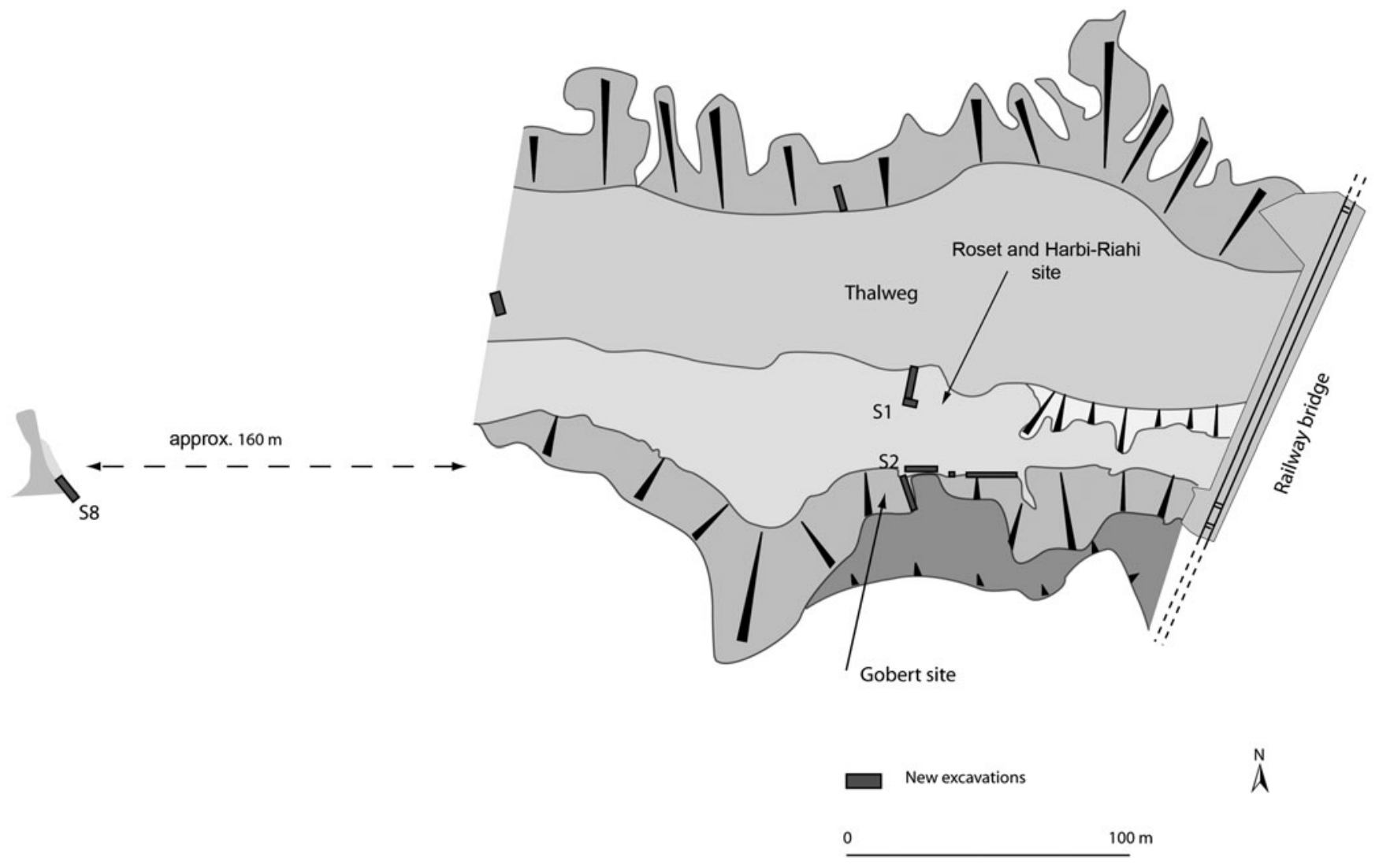

Figure 2. Location of Akarit S8 and other excavations including S1 and S2.

depositional environments or who have had to call upon improbable 'external' factors (massive neotectonism, tsunamis, etc.) to try to explain their observations.

\section{Sondage 8 excavation}

The site, originally described by Page (1972) as 'Site A-3' was re-located during the present survey and excavated as 'Sondage 8 , hereafter 'S8' (Figure 2). It occupies a position close to the summit of the modern gorge-side and a significant way back from (south of) the present thalweg. Whilst there is an erosive unconformity bounding the top of the sequence of interest, the block of sediment containing S8 is not internally divided by deep faulting or disturbed by major deformation, although it is slightly tilted (toppling down outwards/northwards by $2-5^{\circ}$ ) probably indicating that it is backed by faults. Therefore, this sequence still stands largely as it was deposited, hardly affected by the close approach of subsequent steep incision events. We cannot, as yet, describe the general valley geomorphology at the time but both internal evidence and the overall Akarit model, very briefly summarised above, suggest that surface water would have been available in the vicinity of the site.

In 2015 an area of about $9 \mathrm{~m}^{2}$ was excavated by hand. The main archaeological occurrence was identified by a band of dark brown sediment about $4 \mathrm{~cm}$ thick, with a thin lighter brown sediment below this, together designated Excavation Unit (EU) 8005/6 (Figures 3 and 5). All excavated sediments were dry sieved at $5 \mathrm{~mm}$ and in situ finds $>15 \mathrm{~mm}$ three-dimensionally recorded using a total station. During this phase samples for dating and environmental analyses were also collected. The latter included the removal of a small block of consolidated sediment for soil micromorphology from the middle of the occupation area and a series of samples for chemistry and magnetic susceptibility. Further investigations took place in 2019 when the lithostratigraphic sequence was fully described and sediments across the archaeological interval were sampled for cryptotephra analysis and some limited further excavation occurred.

\section{Description of the lithostratigraphic sequence and interpretation}

A description of the S8 sequence (Table 1) shows from the top downwards depths (in metres) above the main Site Datum, and is classified according to very dry (weathered) Munsell colours. Because of variability in the quality of available exposure, the sequence was recorded in two sections, one a few metres to the $\mathrm{SE}$ of the excavated area and the other towards the NE (in square L6), although the stratigraphic continuity of the partial overlap in the ca. $3 \mathrm{~m}$ laterally between the two is demonstrable. Previous main sampling points are noted.

From the field exposures described in Table 1, certain interpretations can be suggested concerning the depositional environments in this sequence (with additional micromorphological observations below). Leaving the superficial phenomena aside (which are probably dominated by Holocene diagenetic and pedogenic overprinting), the whole sequence exposed at S8 represents a rather steady accretive sediment stack, with no major erosive phases and no obvious unconformities or non-sequences. Where not disturbed by bioturbation, fine bedding structure is nearly always present, usually horizontal laminar but occasionally wavy- and even cross-bedded (small ripple-form, very rarely smallest dune-form). The impression is one of a local zone dominated by oscillating very shallow water and wind-flat conditions, probably in at least a semi-arid environment. The 'greenish', often very slightly clayey intervals, usually with reddish iron-oxide traces, suggest minor marshy (reducing) conditions; in the logged sequence, such 'greenish' beds occur mostly below the main archaeological interval (EU 8005/6) but there is a lens of such material 


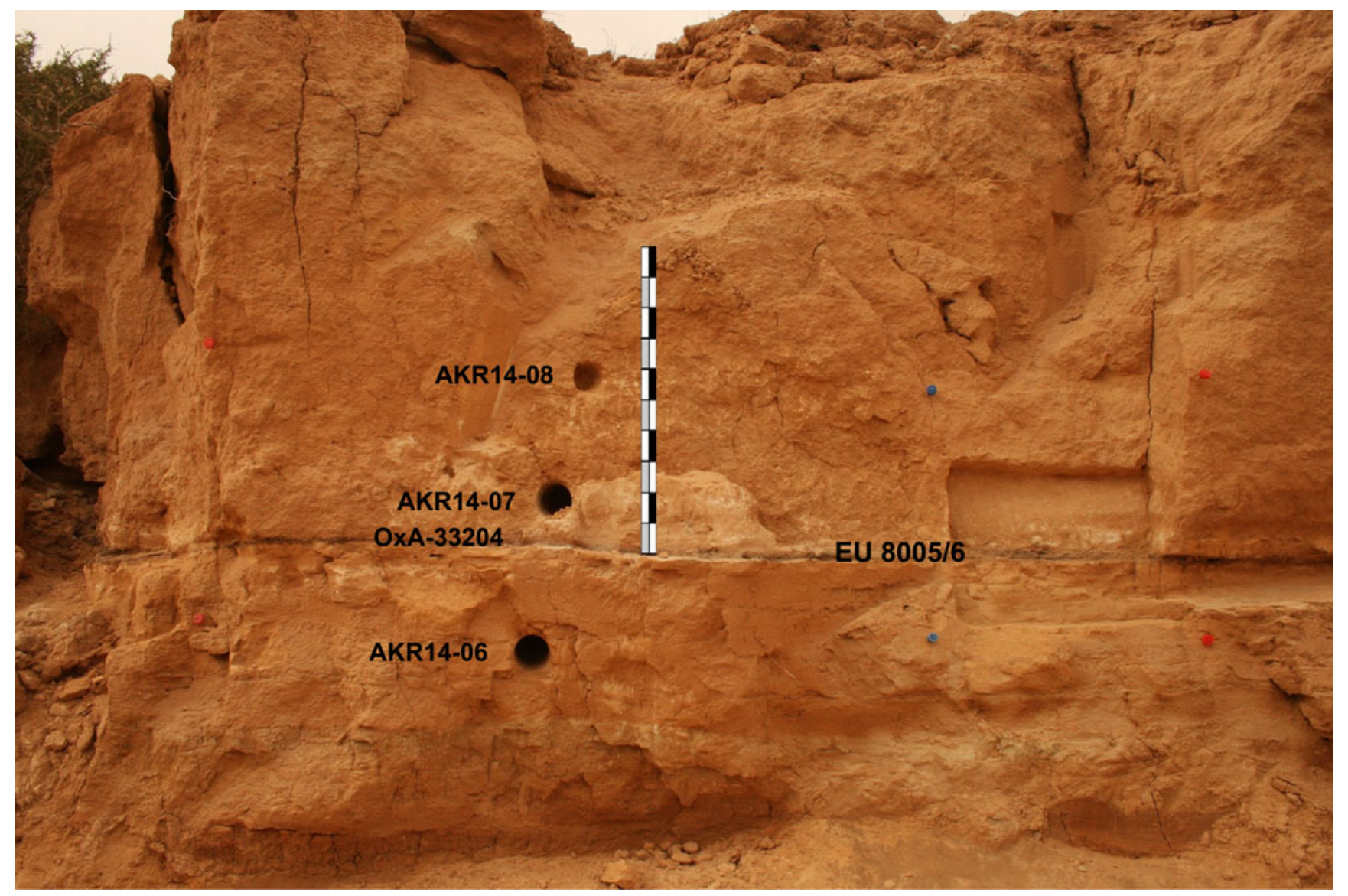

Figure 3. Outer face of Sondage 8 before full excavation. Main archaeological interval (EU 8005/6) which thickens westwards (into the section). OSL gamma-spectrometer holes indicate sample locations (AKR14-06 to 08) and equivalent stratigraphic position of ${ }^{14} \mathrm{C}$ dated Ostrich Egg Shell (OxA-33204) in EU 8005/6. Scale one metre (10 cm intervals). (photo: S.N. Collcutt).

(becoming quite dark in places) well above EU 8005, some $15 \mathrm{~m}$ further west, showing that this facies is part of the recurrent set of motifs in this general stratigraphic interval. Indeed, it is worth noting that the fine bedding is often continuous, usually at scales of tens of metres and, in some cases as much as a hundred metres (allowing for subsequent faulting). Factoring in the more continuous fine carbonate intervals and crusts (Table 1), much of this accretion would appear to have occurred in or immediately around very shallow perennial pools/lakes. It is noteworthy that, in this sequence, there are no signs of ravining, of other sharply erosive events or of mass movement. From a sedimentological point of view, given accretion in a sediment-rich environment, there is no reason to suggest a time scale for the logged sequence (barring the superficial phenomena) of more than a few thousand years (see radiometric dating evidence below).

Because the bedding features in this sequence survive so well, it is unlikely that there was very much vegetation (though perhaps a little more, near marshy accumulations). Thus, the surfaces in the immediate S8 vicinity would usually have been rather low in nutrients. It is therefore probably no coincidence that the main archaeological interval (EU 8005/6) and its adjacent beds show concentrated small-scale bioturbation (dense insect burrows and perhaps some plant rooting); the human presence, on what would have been a temporarily dry surface (perhaps even slightly raised above the hinterland), seems to have introduced significant organic matter, attracting subsequent biological activity (Figures 4 and 5). As these organics decayed or were recycled, original carbonates and gypsum were remobilised somewhat, encouraging the deposition of manganese from groundwater and the formation of fine local carbonate crusts and gypsum crystals at interfaces. This general association (especially with micro-krotovinas) is commonly found at other, otherwise undisturbed archaeological levels at Akarit.

\section{Soil micromorphology, chemistry and magnetic susceptibility}

Two thin sections and seven small bulk sediment samples were analysed for soil micromorphology, chemistry and magnetic susceptibility, the latter to determine the extent of burning in the archaeological horizon EU 8005/6. The thin sections (1A and 1B) were obtained from one monolith box sample taken from within square P6. The bulk sediment samples were taken from small sections both above and within the occupation horizon.

\section{Soil micromorphology}

The thin sections (Table 2) were analysed using a petrological microscope under plane polarised light (PPL), crossed polarised light (XPL), oblique incident light (OIL) and using fluorescence microscopy (blue light - $\mathrm{BL}$ ), at magnifications ranging from $\mathrm{x} 1$ to $\mathrm{x} 200 / 400$. Thin sections were described, ascribed soil microfabric types (SMTs) and microfacies types (MFTs) (Tables 2 and 3), and counted according to established methods (Karkanas and Goldberg 2018; Macphail and Goldberg 2018; Nicosia and Stoops 2017).

\section{Micromorphology results: ( $1 \mathrm{~A}$ and $1 \mathrm{~B})$}

Below EU 8005/6 the sediments are partially bio-worked, cemented gypsum-dominated fine sands (Figure 6). EU 8005/6 itself consists of part gypsum cemented and burrowed fine sands. In contrast to the underlying deposits, it is also characterised by concentrations of variously burnt bone, and rare burnt mineral material (Figures. 6-12). The presence of only trace amounts of 
Table 1. Description of lithostratigraphic sequence.

\begin{tabular}{|c|c|}
\hline SE 9.29+ & In SE section, disturbed material below modern surface. \\
\hline SE 9.29-9.09 & $\begin{array}{l}\text { 'Rubble', red/ginger along tight boundaries of component elements (ca. } 2-50 \mathrm{~mm} \text { diameter); } 7.5 \mathrm{YR} 5 / 8 \text { at brightest, down to white or } \\
\text { light buff } 7.5 \mathrm{YR} 6 / 3 \text {; includes many small }(<1 \mathrm{~cm} \text { ) gypsum crystals but there is significant carbonate in the groundmass; appears to be a } \\
\text { rooting zone at the base of the (modern?) soil; irregular, invasive lower boundary }(5-10 \mathrm{~cm} \text { vertical range). }\end{array}$ \\
\hline SE 9.09-8.44 & $\begin{array}{l}\text { Thick cemented bed; much bioturbate disturbance in section but residual, very continuous horizontal laminations, showing best as } \\
\text { thin white lines; dominantly carbonate silt with a little fine sand; no visible coarse clasts; white to } 7.5 Y R \text { R } 7 / 3 \text {; coarser crystals at base } \\
\text { still dominantly carbonate; no macro-crystalline gypsum at any level; basal few centimetres may be disturbed ripple-bedding, } \\
\text { approximately } 2 \mathrm{~cm} \text { amplitude, }<10 \mathrm{~cm} \text { frequency; irregular but sharp lower boundary. }\end{array}$ \\
\hline SE 8.44-8.32 & $\begin{array}{l}\text { Much less cemented; light greenish grey colour } 5 Y 7 / 1-2 \text {; small }(<1 \mathrm{~cm}) \text { irregular ginger Fe-traces; carbonate-rich fine sand, plus some } \\
\text { bright grains; traces of horizontal laminae survive; rare white laminae; only very slight textural variation in different sets of laminae; } \\
\text { lower boundary diffuse and gradational (over the basal } 5 \mathrm{~cm} \text { ). }\end{array}$ \\
\hline SE 8.32-7.94 & $\begin{array}{l}\text { Fine sand, carbonate-rich, possibly a gypsum (detrital) contribution but never differentiates into in situ matrix crystals; blotchy colours } \\
\text { but generally buff sandy, reddening to 5YR } 7 / 6 \text { or even } 7.5 Y R 6 / 6 \text { in places; laminated, possibly some very low-angle cross-bedded sets } \\
\text { (difficult to observe due to dry exposure and diagenesis); perhaps thickening northwards and cross-beds slightly dipping northwards; } \\
\text { rare small carbonate nodules; rare restricted carbonate laminae (never more than } 5 \mathrm{~cm} \text { wide extent); increasingly cemented } \\
\text { downwards; very irregular ( } 10+\mathrm{cm} \text { relief over lateral scale of } 1 \mathrm{~m} \text { ) cemented (welded) boundary with unit below. }\end{array}$ \\
\hline \multirow[t]{2}{*}{$\begin{array}{l}\text { SE } 7.94-7.59 \\
\text { and } \\
\text { below }\end{array}$} & $\begin{array}{l}\text { Increasingly cemented fine-sandy silt; originally bedded but showing considerable disturbance from bioturbation and/or } \\
\text { recrystallisation; rather wavy bedding, perhaps with some true ripple-forms; no vertical/columnar structure (suggesting that this } \\
\text { waviness is not a secondary effect); not quite so massive/dense as the NE } 9.09-8.44 \text { interval; where well cemented, nearly white, less so } \\
\text { to } 7.5 Y R \text { R } 7 / 6 \text { elsewhere; base of SE exposure. }\end{array}$ \\
\hline & LOG MOVED FROM SE TO NE \\
\hline NE 7.86-7.70 & $\begin{array}{l}\text { Top of the NE section [equivalent to part of the } 7.94-7.59 \text { interval in the SE section]; heavily cemented, carbonate-dominant, fine to } \\
\text { finest medium sand; white blotches, redder at base, } 7.5 \mathrm{YR} 7 / 4 \text { to } 7 \mathrm{YR} 7 / 6 \text { in basal centimetre. }\end{array}$ \\
\hline $\begin{array}{l}\text { NE } 7.70-7.69 \\
\text { or } 7.68\end{array}$ & $\begin{array}{l}\text { Excavation Unit } 8001 \text {; whitish band (very hard carbonate), nodules, thickening westwards; } 10 \mathrm{YR} 8 / 3 \text { or whiter; relatively sharp lower } \\
\text { boundary. }\end{array}$ \\
\hline NE 7.69-7.64 & $\begin{array}{l}\text { Excavation Unit } 8002 \text {; dense silty sand and fine-sandy silt; originally laminated; 'ghost' micro-krotovinas appearing; } \\
\text { carbonate-dominated; 8YR 7/6; relatively sharp, wavy, lower boundary. MS5 sample mid-way through Unit } 8002 \text {. OSL AKR14-08 centred } \\
\text { on this interval. }\end{array}$ \\
\hline NE 7.64-7.56 & $\begin{array}{l}\text { Cemented (hard), carbonate-dominated, finest sand and silt; probably originally bedded but now showing 'ghost' micro-krotovinas; } \\
\text { tiny }(1-10 \mathrm{~mm}) \text { carbonate nodules; } 7.5 \mathrm{YR} 7 / 6 \text { with slightly lighter krotovinas-fills; diffuse lower boundary. }\end{array}$ \\
\hline NE $7.56-7.51$ & Extremely carbonate-rich coarse silt, cemented; 'ghost' micro-krotovinas; 7.5YR 8/4; micro-bioturbated lower boundary. \\
\hline NE 7.51-7.48 & $\begin{array}{l}\text { Excavation Unit } 8003 \text { and MS4 sample; finest sand and silt; probably bedded (planar laminae) but micro-krotovinas; } 7.5 \text { YR } 7 / 6, \text { very } \\
\text { slightly redder (7YR) at base. }\end{array}$ \\
\hline NE 7.48-7.44 & $\begin{array}{l}\text { Heavily disturbed (micro-bioturbated), probably a mixture of NE } 7.56-7.51 \text { and NE } 7.51-7.48 \text { facies sediments; variegated; } \\
\text { non-quartzitic stone line (1-4 mm) at base (probably the turbation base but possibly deflation); the lighter facies is probably } \\
\text { Excavation Unit } 8004 \text {. OSL AKR14-07, possibly also cutting a little into underlying interval. }\end{array}$ \\
\hline NE 7.44-7.39 & $\begin{array}{l}\text { Reasonably well bedded, very well sorted fine sand, lightly cemented; } 7.5 Y R \text { 7/6, downwards to } 7 \text { YR } 7 / 6-7 \text {. MS3 sample cuts through } \\
\text { top. }\end{array}$ \\
\hline $\begin{array}{l}\text { NE } 7.39-7.36 \\
\text { Variable } \\
\text { thickness }\end{array}$ & $\begin{array}{l}\text { Excavation Units } 8005 / 6 \text {; wavy and sometimes as much as } 6 \mathrm{~cm} \text { thick; the 'layer' is bounded by discontinuous, lightly cemented whitish } \\
\text { crusts, usually slightly arcuate above (concave-down) and below (concave-up) but sometimes more planar and even multiple, normally } \\
\text { lying in a matrix of sandy silt; between these light crusts, possibly penecontemporaneously developed darker (chocolate brown } 7.7 Y R \\
3 / 2 \text { or lighter chroma where faded, slightly depleted in carbonate in comparison with all other units in this sequence) silt (with Mn and } \\
\text { weak alkali-soluble organic matter), over a light-coloured (orangey), apparently slightly coarser than usual fine carbonate sand (but } \\
\text { also slightly clayey); these two facies, plus the 'normal' buff-coloured silts from immediately above and below, then intimately } \\
\text { contorted and interpenetrated by micro-krotovinas (often } 5-15 \mathrm{~mm} \text { long ovals/tubes), probably mostly from infauna (insects); tiny } \\
\text { neo-gypsum crystals in dark facies; very little charcoal at this exposure point (increasing westwards), although what does exist is } \\
\text { angular (fragmented by bioturbation, crystallisation, etc.), rather than rounded (thus, not transported); lithic artefacts and finest } \\
\text { debitage, rare very weathered bone fragments, some burnt, objects commonly lying more or less horizontally (save when actually } \\
\text { within a bioturbation structure). MS2 sample from dark facies; the MS6 and MS7 samples were taken from Unit } 8005 \text { (further west in } \\
\text { the } 2015 \text { excavated area). Block sample OAK } 15 \text { square P6, centred on Unit } 8005 \text {. From dark facies: OxA-X-2500-24 AKR-12/3 charcoal } \\
\text { (Unident); OxA-X-2500-23 AKR-12/2 charcoal (Monocotyledon). From lighter facies: OxA-33204 OES-14/OAK15-100. }\end{array}$ \\
\hline NE $7.36-7.31$ & $\begin{array}{l}\text { Base rising to } 7.33 \text { westwards; cemented finest sand and coarse silt; } 7.5 Y R 7 / 5 \text {; irregular and wavy base, pierced by vertical biotraces } \\
\text { (rooting?). }\end{array}$ \\
\hline NE $7.31-7.15$ & $\begin{array}{l}\text { Very well sorted fine sand; laminations (very slightly wavy) surviving in places, reinforced by cementation; } 7.5 \text { YR } 7 / 6 \text {; considerably } \\
\text { fewer bioturbation structures. }\end{array}$ \\
\hline NE $7.15-7.13$ & $\begin{array}{l}\text { Zone with gritty (neo-?) gypsum crystals, probably due either to better cemented layer below or to recent/modern plant root layering } \\
\text { at this junction; slightly speckled, redder/whiter. }\end{array}$ \\
\hline NE 7.13-7.06 & $\begin{array}{l}\text { Dense, cemented, fine-sandy coarse silt; blotchy reduced colours, 10YR } 7 / 3 \text { at the 'greenest' but colours often browner; rare, very small } \\
\text { scale ginger Fe-traces in otherwise massive ground; a few neo-gypsum crystals at the base. OSL AKR14-06, possibly also cutting a little } \\
\text { into underlying interval. }\end{array}$ \\
\hline NE $7.06-6.93$ & Mostly finely laminated, well sorted finest sand; dense; a few small krotovinas visible, especially at base; 8YR $7 / 6$. MS1 sample at top. \\
\hline NE 6.93-6.81 & $\begin{array}{l}\text { Coarse silt and finest sand; rare ginger Fe-traces; } 2.5 Y 7 / 2 \text { at the 'greenest' but often browner; note that a plastic roll can never be } \\
\text { developed with this sediment (insignificant clays). }\end{array}$ \\
\hline
\end{tabular}




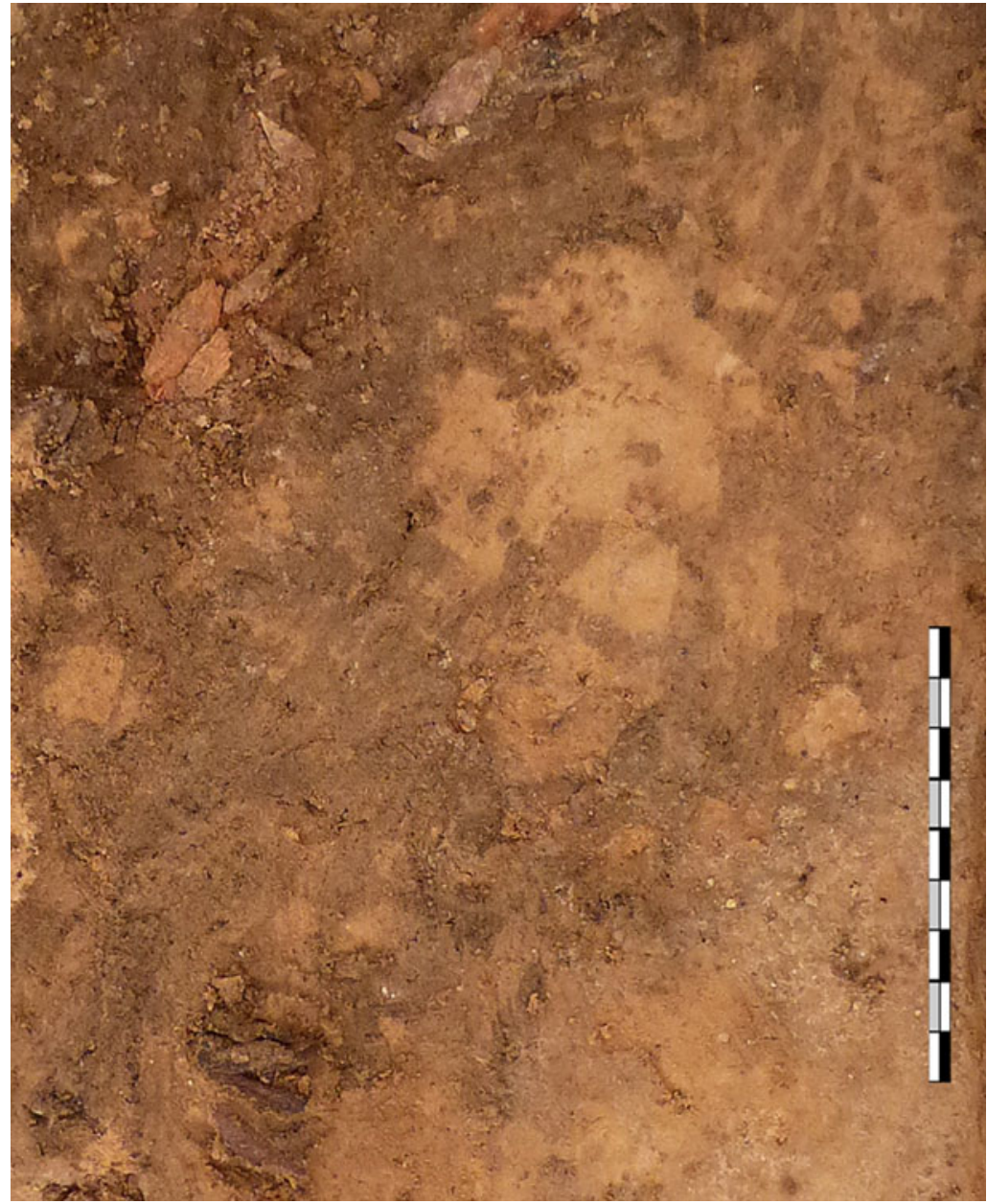

Figure 4. Towards base of main archaeological interval (Excavation Units 8005/6, square L5), excavation surface showing penecontemporaneous bioturbate structures (buff colour) in plan (scale $10 \mathrm{~cm}$ )( photo: A.J. Roberts). calcitic ash (Figure 13) and charcoal may be due to taphonomic effects (leaching and winnowing) (cf. Goldberg and Macphail 2012; Macphail et al. 2012; Mallol et al. 2017). The deposit was also affected by tiny insect and worm burrows associated with likely secondary phosphate from overlying possibly guano-rich layers (Figures 14 and 15).

\section{Bulk soil chemistry and magnetic susceptibility}

A five-parameter analysis routine, developed and adapted for soil prospection and bulk analysis of occupation soils and features, was applied to all the seven bulk samples analysed. These analyses provide information on phosphate, iron and other magnetic components and total organic matter in soils and sediments, and its relationship to phosphate (Viklund et al. 2013). Analysed parameters comprise organic matter (loss on ignition [LOI], Carter 1993), two fractions of phosphate (inorganic [Cit-P], and the sum of organic and inorganic [Cit-POI]) (Linderholm 2007), magnetic susceptibility ([MSlf] and after oven heating at 550 degrees $\mathrm{C}$ to approximate total potential magnetic susceptibility of the natural background [MS550], in this case a good proxy for iron content, Clark 1996; Linderholm 2007).

\section{Results of chemistry and magnetic susceptibility}

The identification of a burnt, bone-rich, occupation horizon is consistent with enhanced MS, marked phosphate concentrations and a noticeably higher LOI, compared to sediments both above and below EU 8005/6 (Table 4). The occurrence of suggested hydroxylapatite in burrowed-down soil indicates probable mixing with an overlying hypothetical guano-rich (bird presence) micro-layer (see Discussion section). Above EU 8005 (in EU 8002 and EU 8003), heightened proportions of organic phosphate compared to inorganic phosphate (Pquota; max 2.4) may record inputs of organic phosphate from guano (Table 4).

\section{Dating studies (optical luminescence, radiocarbon and tephrochronology)}

Optically stimulated luminescence (OSL) dating provides an estimate of the time elapsed since luminescent minerals, such as quartz or feldspar, were last exposed to sunlight (Huntley et al. 1985; Aitken 1998). It has become a well-established dating technique in Quaternary science and the methodology is described in various publications (e.g. Duller 2004; Lian and Roberts 2006). Three OSL samples were taken across the archaeological deposits (Figure 3) and they were prepared and measured according to methods described in Mirazón Lahr et al. (2016). Sample AKR14-08 came from $50 \mathrm{~cm}$ above the main find horizon EU 8005/6, AKR14-07 from $10 \mathrm{~cm}$ above and AKR14-06 from $30 \mathrm{~cm}$ beneath the main find horizon. The results show remarkable internal consistency and none of the dates are distinguishable at one sigma (Table 5).

The suitability of ostrich eggshell as a material for radiocarbon dating was explored several decades ago (Freundlich et al. 1989), and the method is now routinely applied to such material spanning the last 50,000 years from different parts of the world including Africa (e.g. Kandel and Conard 2005; Orton 2008; Miller et al. 2014). Three AMS radiocarbon assays were attempted on separate ostrich eggshell fragments (Table 6). They were selected, respectively, from the base of the archaeological horizon (unit EU 8006), from within the archaeological horizon (EU 8005/6) and from close to its top. Only the one from EU 8006 succeeded in producing a result. A fourth AMS sample was taken from an ostrich 


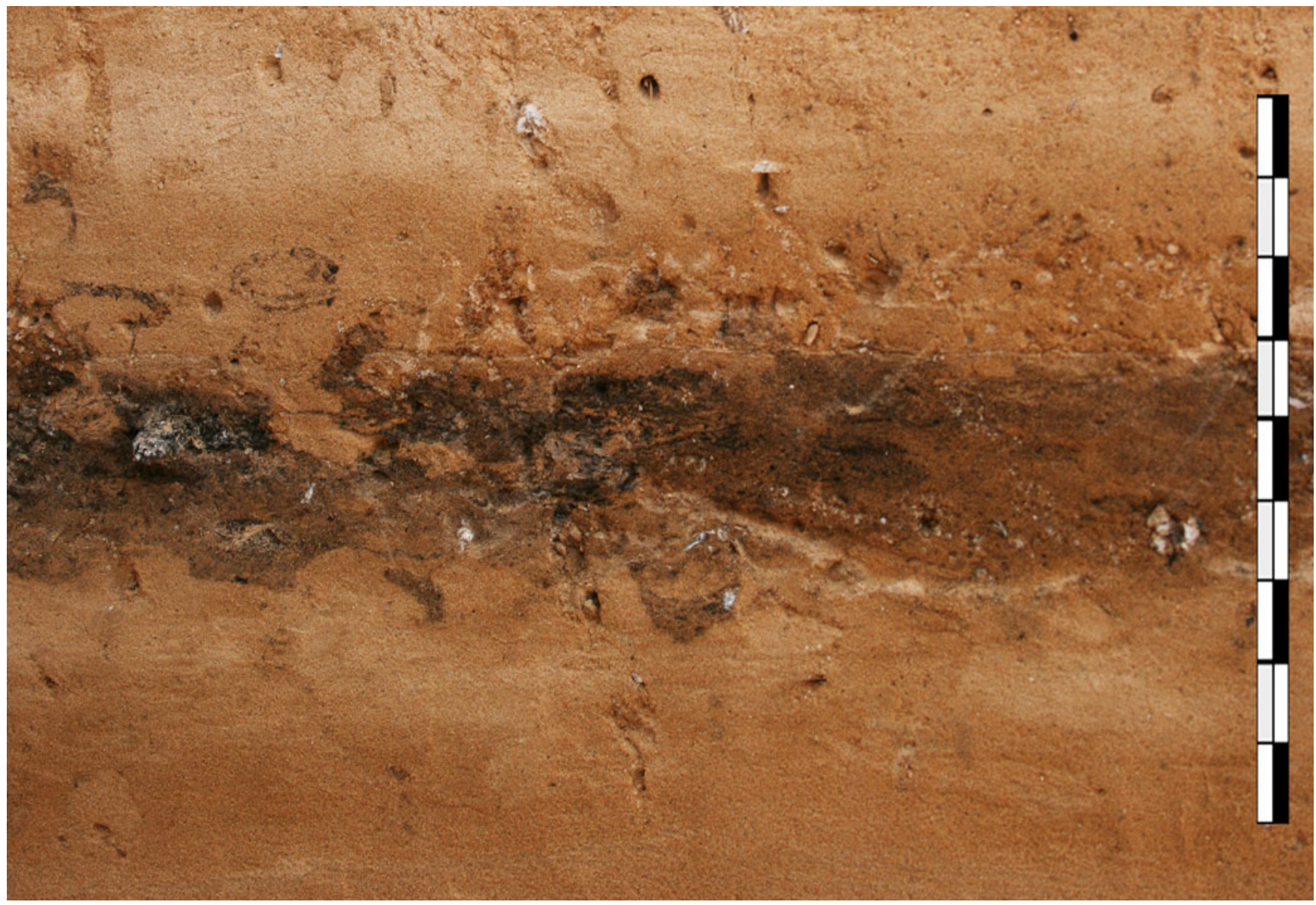

Figure 5. Main archaeological interval (Excavation Units 8005/6, square L6), vertical section 2019 (scale $10 \mathrm{~cm}$ ) (photo: S.N. Collcutt).

eggshell fragment in the immediately adjacent ravine (lateral to the main wadi) where another layer, S-8(A), very rich in fauna and MSA lithic artefacts had been exposed in a position near the base of the current incision. Significantly, this deeper cultural layer was separated from EU $8005 / 6$ by an undisturbed stack of strata at least 4 metres thick. The obtained result (OxA-33205) from this eggshell is very close to the working limit of radiocarbon and should be considered a minimum age only. Despite the slight variance between the single AMS calibrated date and the OSL age estimates, all of the dates fall within the equivalent of MIS 3 (Marine Isotope Stage 3) of the global oceanographic record (Castañeda et al. 2009).

The sediments were examined for the presence of microscopic volcanic ash (cryptotephra) layers, which could provide additional chronological constraints for the site. Such cryptotephra layers have been identified in other key archaeological sites across North Africa (e.g. Barton et al. 2015). Potential volcanic sources include the productive Italian volcanoes located $\sim 1000 \mathrm{~km} \mathrm{NE}$ from Akarit, and the volcanic islands of the Canary Islands and Azores located $2500 \mathrm{~W} \mathrm{~km}$, and $3500 \mathrm{~km} \mathrm{NW}$ from the site, respectively. Sediments were sampled across the archaeological interval, as well as from above and below EU 8005/6 (Figure 16). All samples were wet sieved through a $60 \mu \mathrm{m}$ and $25 \mu \mathrm{m}$ mesh and processed using the heavy liquid floatation method outlined by Turney (1998). This procedure allows the volcanic glass shards, with a density between 2 and $2.9 \mathrm{~g} / \mathrm{cm}^{3}$, to be effectively separated from the sediment. Samples were prepared alongside blanks, which demonstrated that there was no laboratory contamination. The number of glass shards per gram of dried sediment $(\mathrm{s} / \mathrm{g})$ from the samples that were taken vertically through the archaeological interval are shown in Figure 16. A significant horizon was identified $22-24 \mathrm{~cm}$ above the archaeological layer (EU 8005/6), which contains $\sim 27 \mathrm{~s} / \mathrm{g}$. Shards here were clear and fluted with stretched vesicles. This horizon was targeted for geochemical analysis so that a potential source of this eruption event could be identified. Sediments that contained lower concentrations of glass shards $(<10 \mathrm{~s} / \mathrm{g})$ could not be geochemically characterised due to the low number of the shards and their morphology.

\section{Description of lithic assemblage}

The artefacts described here all come from S8 EU 8005/6. They consist of a total of 516 pieces of debitage and cores and 25 retouched tools. They are classified according to the methods outlined in Geneste (1985).

\section{Raw material}

The most common flint types recorded in the assemblage are identified as Cretaceous Senonian (grey and light brown) and Eocene (white-ish) flint. The sources of this flint can be considered 'local' according to the criteria devised by Geneste (1988): local being within a radius of $5 \mathrm{~km}$, regional from 5 to $20 \mathrm{~km}$ and exotic found up to $80 \mathrm{~km}$ away. In this instance, good quality raw materials are available in the Segui Formation (Cretaceous origin with Late Miocene alteration) that outcrops in relative abundance in drainage systems within $5 \mathrm{~km}$ of Oued el Akarit.

\section{Debitage}

The cores comprise 16 Levallois examples (including two Levallois core fragments), plus two cores on a flake and an unidentified core form (Table 7). With respect to the method of knapping, the 


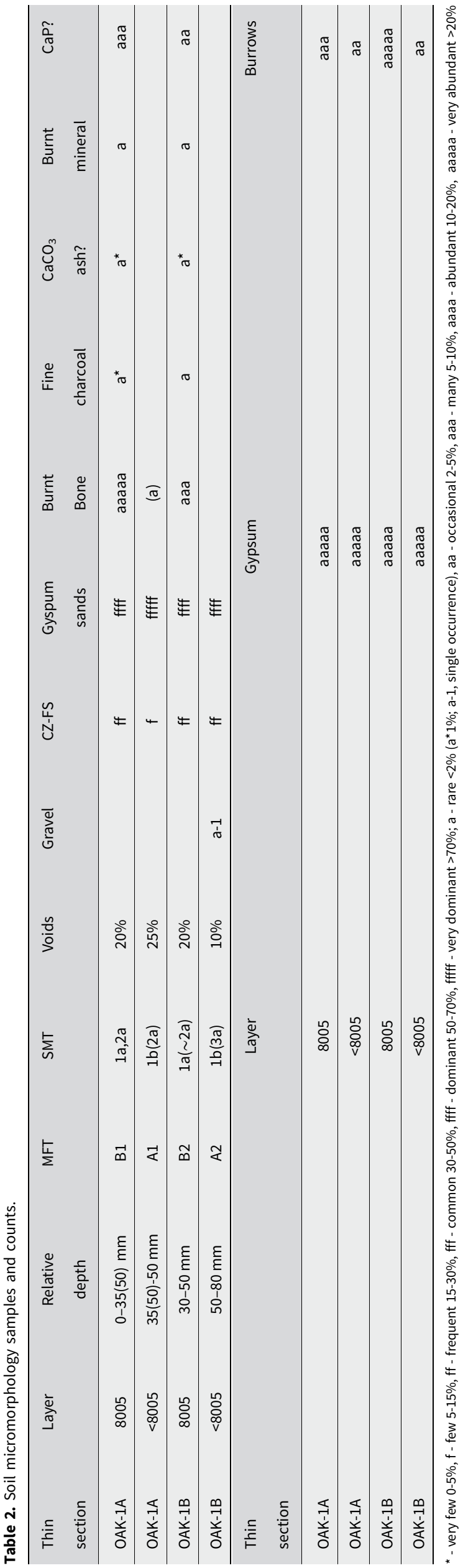

Levallois cores are characterised by lineal preferential reduction. This describes the method whereby a single flake is detached for each prepared surface using the Levallois method (Inizan et al. 1992; Boëda 1994). Both the cores and flakes in the assemblage indicate the frequent use of direct percussion with a hard hammer. The flakes consist of a mixture of cortical and non-cortical examples. If the smaller flakes ( $<20 \mathrm{~mm}$ in length) are excluded, it shows that roughly half $(96 / 197)$ have either complete coverage or some degree of cortex on their dorsal surfaces, and is an indication that whole cobbles were imported and knapped on site.

Amongst the debitage is a high representation of small flakes and broken fragments which, together with the presence of pieces of shatter, including tiny fragments of less than $2 \mathrm{~mm}$, suggests that the flint scatter had not been greatly disturbed. The flakes are all in sharp condition and refitting evidence (see below) indicates that they must have been incorporated quite quickly into the soft sediments leaving no obvious sign of long-term surface exposure (trampling, wind winnowing, wash) that might have led to more pronounced disruption of the flint scatter. During excavation we also noted an absence of any preferential orientation of the flint that might have implied sorting by wind action or by hydraulic processes. Many of the artefacts are burnt (Figure 17) and these are scattered across the excavated squares.

Study of the lithic industry also identified 25 retouched tools, the great majority of which are side-scrapers (18 or $72 \%$ ). The tools are on various supports: $24 \%$ on Levallois flakes, $36 \%$ on simple flakes/blades and resharpening flakes, and $8 \%$ on core-edge removal flakes (éclats débordants). In total a quarter of all the tools were made on Levallois flakes, which probably accounts for the relatively low proportion of Levallois flakes to cores in the whole assemblage. Only five of the tools are burnt.

The majority of tools are scrapers (Figure 18), of which 7 are single straight side scrapers ( $28 \%$ of tools), 5 are single concave side scrapers (20\% of tools), 3 double side scrapers, 2 offset (déjeté) scrapers and 1 straight transverse scraper. The rest of the tools consist of a notch, a denticulate, a backed knife, a Mousterian point and a composite tool.

Regarding the distribution of these retouched tools, they are mainly concentrated in squares P5 and P6 (Table 8). However, the distribution map of tools according to type (Figure 22) suggests they might have been part of two clusters: one focusing in squares Q6, P5 and P6, consisting of simple and double scrapers, denticulate, notch, naturally backed knife and a Mousterian point; the other occurring in squares O5, O6, N5 and M5 with simple scrapers, a transverse scraper and a composite tool (Figure 19). Taken at face value this could indicate different production or activity zones or possibly a re-use of the site but one in which intensive use of scrapers was employed perhaps for hide preparation.

\section{Refitting evidence}

By refitting flakes to cores it is possible to reconstruct the chaine opératoire in this lithic technology, including the different stages leading to the elaboration of flake surfaces to produce Levallois flakes. In EU 8005/6 one extensive core reduction sequence can be reconstructed. It was made of good quality Senonian flint and consists of a sequence of 26 flakes that could be refitted to a Levallois core and a related fragment. Two thirds of the refitting flakes were either cortical or partially cortical and confirmed that the whole cobble had been carried to the site. In terms of morphology, the refitted cortical flakes were on average thinner than the non-cortical flakes (see Table 9). Within the sequence were also two discarded Levallois flakes (broken during manufacture), both thin and regular and one of them being almost square in shape.

Flake platforms (butts) of the refitting flakes are generally faceted (15 out of 27) or dihedral faceted (with two intersecting flake scars $=2$ ) $($ Table 10). Prominent bulbs on their ventral 
MFT B1/SMT 1a, 2a

OAK-1A $\quad 0-35(50) \mathrm{mm}$

SM: pale greyish brown gypsum-rich coarse silt-very fine sands (SMT 1a), with frequent broad burrow fills of gypsum-free blackish brown fine sandy loam (SMT 2a); Microstructure: massive, $20 \%$ voids, simple packing voids, open channels (gypsum crystal infilled); Coarse Mineral: moderately poorly sorted, dominant fin (gypsum crystal infilled); Coarse Mineral: moderately poorly sorted, dominant fin
sand-size euhedral gypsum fine sand and frequent quartz and feldspar-based sand-size euhedral gypsum fine sand and frequent quartz and feldspar-based
coarse silt-very fine sands, with few medium and coarse sand-size gypsum rock coarse silt-very fine sands, with few medium and coarse sand-size gypsum rock
fragments; Organic and Anthropogenic: very abundant burnt bone (max $10 \mathrm{~mm}$ fragments; Organic and Anthropogenic: very abundant burnt bone (max $10 \mathrm{~mm}$
fragmented example), with heated, rubefied and rare calcined variants, trace of fin fragmented example), with heated, rubefied and rare calcined variants, trace of fine
charcoal ( $\max <0.5 \mathrm{~mm})$, trace of possible calcitic ash and rare likely burnt fine charcoal (max $<0.5 \mathrm{~mm}$ ), trace of possible calcitic ash and rare likely burnt fine mineral material; Fine Fabric: SMT 1a: dusty and dotted pale greyish brown (PPL),
moderately high interference colours (close porphyric with single grain, stipple moderately high interference colours (close porphyric with single grain, stippl
speckled and crystallitic b-fabric, XPL), grey and very pale yellow (OIL), trace speckled and crystallitic b-fabric, XPL), grey and very pale yellow (OIL), trace
amounts of possible relict humic staining, rare very fine charcoal and very fine amounts of possible relict humic staining, rare very fine charcoal and very fine
calcitic ash; SMT 2a: very dusty blackish brown (PPL), isotropic (open porphyric, undifferentiated b-fabric, XPL), pale yellowish brown (OIL), trace of very fine charcoal; Pedofeatures: Crystalline: very abundant very fine cementing microcrystalline gypsum (and as channel hypocoatings) and loose infills of fine sand-size lenticular gypsum, with many dark isotropic and BL autofluorescent burrow fills of fine sandy loam indicating presence of hydroxylapatite probable mixing with a hypothetical bird occupied guano-rich- deposit; Fabric: many thin and broad burrows, sometimes mixing in gypsum-free fine deposit.

$35-50 \mathrm{~mm}$

MFT A1/SMT 1b (2a)

SM: pale greyish brown strongly gypsum-rich coarse silt-very fine sands (SMT 1b) with very few fine channels of yellowish brown fine sandy loam (SMT 2a),

Microstructure: massive, $25 \%$ voids, simple packing voids and channels; Coarse Mineral: as above; Organic and Anthropogenic: ; Fine Fabric: SMT 1b: dusty very pale greyish brown (PPL), moderately high interference colours (close porphyric with greyish brown (PPL), moderately high interference colours (close porphyric with
single grain, stipple speckled and crystallitic b-fabric, XPL), patchy grey and very pale yellow (OIL), minerogenic; Pedofeatures: Crystalline as above, and occasional thin and broad burrows, sometimes mixing in gypsum-free fine deposit.

MFT B2/SMT 1a ( 2a)

OAK-1B $\quad 30-80 \mathrm{~mm}$

$30-80 \mathrm{~mm}$

SM: Thinly and broadly burrowed ( $20 \%$ voids), pale greyish brown gypsum-rich

coarse silt-very fine sands (SMT 1a), with rare fine channel infills of dark brown fin sandy loam ( SSMT 2a), many fine heated and burnt bone ( $\max 2 \mathrm{~mm}$ ), rare fine sandy loam ( SMT 2 a), many fine heated and burnt bone (max $2 \mathrm{~mm}$ ), rare fine
charcoal ( $\mathrm{max} 1 \mathrm{~mm}$ - in channels), rare probable burnt mineral material including rubefied fine material. Occasional probable secondary hydroxylapatite

rubefied fine material. Occasional probable secondary hydroxylapatite

gypsum, including loose broad channel infills, and with very abundant fine and gypsum, including loose

50-80 mm

MFT A2/SMT 1b (3a)

SM: Compact (10\% voids), broadly layered pale greyish brown strongly gypsum-rich coarse silt-very fine sands (SMT 1b) with frequent pale greyish brown silty clay dominated by silt size gypsum crystals (SMT 3a) in channels, with examples of $\mathrm{mm}$-size micritic limestone and coarse sand size gypsum crystal. Very abundan broadly layered microcrystalline gypsum cementing layered silts and fine sands, with occasional thin and broad burrows.

SM: Fine Fabric: SMT 3a: cloudy pale greyish brown (PPL), moderately high interferen
Preliminary Interpretation and Comments

8005 - combustion zone

Pale greyish brown gypsum-rich coarse silt-very fine sands, with frequent broad burrow fills of gypsum-free blackish brown fine sandy loam. Very abundant burnt bone $(\max 10 \mathrm{~mm}$ fragmented example), with heated, rubefied and rare calcined variants, trace of fine charcoal $(\max <0.5 \mathrm{~mm})$, trace of possible calcitic ash and rare likely burnt fine mineral material, are present. Layer is characterised by very abundant very fine cementing microcrystalline pypsum (and as charcenter by with with dark isotropic and occasional blue light (BL) autofluorescent burrow fills of fine sandy loam indicating presence of hydroxylapatite, and many thin and broad bursows, sometimes (O) $=1.9-10 . \mathrm{Pqu}$. LOI - 1.9-10.1; Pquota $=0.56-1.1 ; 8005$ sediment: MS $=8 ; P=310 ; 1.1=1$. sample series: MS = 6-11; P = 340-380; LOI = 0.8-1.7; Pquota = 1.7-2.4

partially gypsum cemented and burrowed 8005 'combustion zone' of probable trampled occupation floor spread, characterised by concentrations of variously burnt bone, and rare burnt mineral material, while only trace amounts of calcitic ash and charcoal may be due to taphonomic effects (leaching and winnowing). Identification of bone-rich combustion zone consistent with enhanced MS, marked phosphate concentrations and noticeably higher $\mathrm{LOI}$, compared to 8005 sediment and 8003 sample series. Presence of suggested hydroxylapatite in burrowed-down soil indicates probable mixing with a hypothetical overlying bird occupied guano-rich-deposit. Outside of the combustion zone heightened Pquotas may record inputs of organic phosphate from guano.

Below 8005

Pale greyish brown strongly gypsum-rich coarse silt-very fine sands with very few fine channels of yellowish brown fine sandy loam.

Partially bioworked cemented gypsum dominated fine sands.

8005 - combustion zone

Thinly and broadly burrowed, pale greyish brown gypsum-rich coarse silt-very fine sands, with rare fine channel infills of dark brown fine sandy loam, many fine heated and burnt with rare fine channel inflls of dark brown fine sandy loam, many fine heated and burnt material including rubefied fine material. Occasional probable secondary hydroxylapatite material including rubefied fine material. Occasional probable secondary hydroxylapatite impregnations and channel fills, very abundant microcrystalline and lenticular gypsum, including loose broad channel infills, and with very abundant fine and broad burrows overall. 'Combustion zon' spread, as in OAK-1A, but with thin burrows with loose inflils of fine charcoal and likely burnt mineral material - of presumed hearth origin. The layer was also affected by burrows associated with suggested secondary phosphate from overlying guano-rich layers(?).

Below 8005

Compact, broadly layered pale greyish brown strongly gypsum-rich coarse silt-very fine sands with frequent pale greyish brown silty clay dominated by silt size gypsum crystals in channels, with examples of $4 \mathrm{~mm}$-size micritic limestone and coarse sand size gypsum crystal. Very abundant broadly layered microcrystalline gypsum cementing layered silts and fine sands, with occasional thin and broad burrows.

Gypsum cemented seemingly layered fine sands, possibly recording episodic sedimentation and gypsum cementation. 


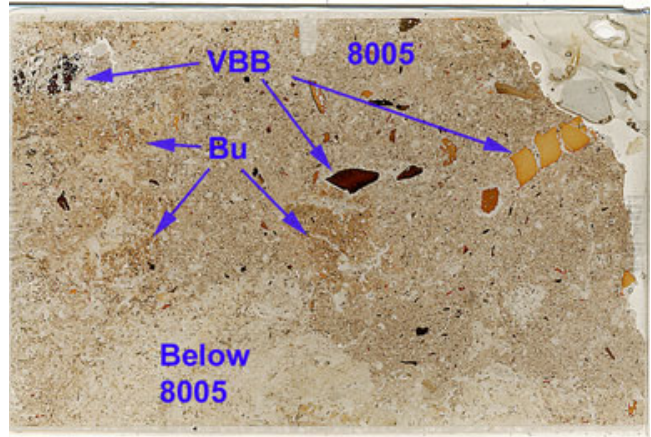

Figure 6. Scan of OAK-1A; weakly humic combustion zone (8005) containing variously burnt bone fragments (VBB), over gypsum-cemented fine sands (Below 8005). Note broad burrows with darker (phosphate?) infills (Bu). Frame width is $\sim 50 \mathrm{~mm}$. All scans and photomicrographs by R. Macphail.

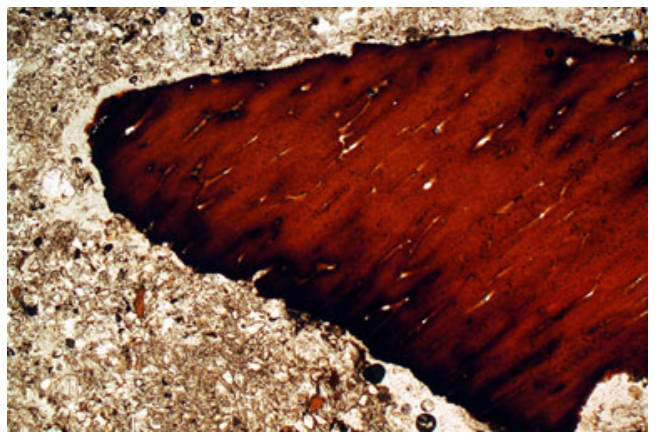

Figure 7. Photomicrograph of OAK-1A; combustion zone with rubefied burnt bone. Plane polarised light PPL, frame width is $\sim 4.62 \mathrm{~mm}$.

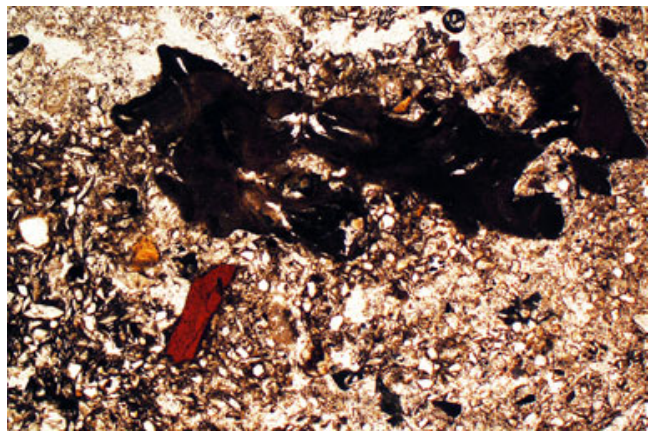

Figure 8. Photomicrograph of OAK-1A; combustion zone with (black) calcined burnt bone. PPL, frame width is $\sim 4.62 \mathrm{~mm}$.

surfaces, frequently accompanied by bulbar scars (esquille bulbaire), indicate that they were made with a hard percussor. In the other largest category are flakes with plain and lipped butts (5) and likely also made using hard hammer percussion.

The reduction sequence reveals three Levallois flakes made using the lineal Levallois (preferential) method, with centripetal preparation and hard hammer percussion. The sequence can be split into four phases:

Phase 1 (Figure 23): the objective was to prepare a sub-circular Levallois tortoise core and to detach from its upper surface a preferential Levallois flake. However, this phase failed to detach the desired flake. The result is a broken piece (Figure 23, nos 402 and 671) due to a simple knapping error, namely a mis-hit (bounce) as the flake was struck.

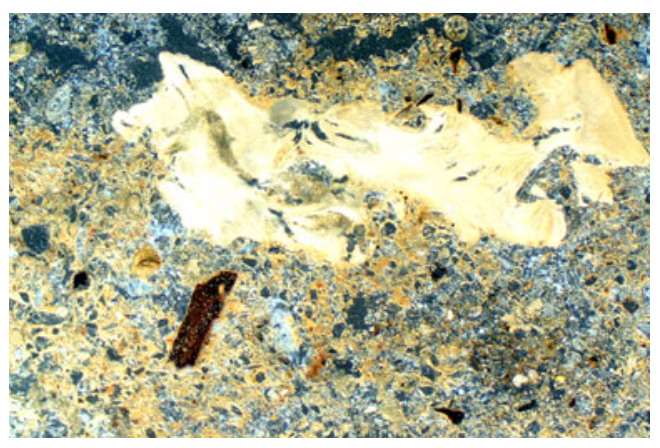

Figure 9. As Figure 8, calcined bone is white, under oblique incident light (OIL).

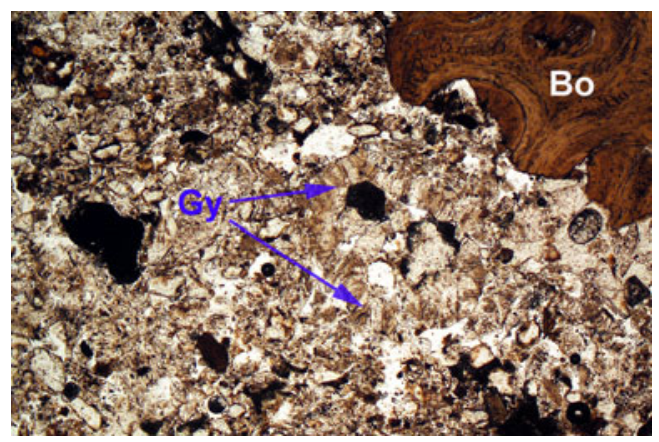

Figure 10. Photomicrograph of OAK-1A; combustion zone with rubefied burnt bone (Bo) and gypsum cementation (Gy). PPL, frame width is $\sim 4.62 \mathrm{~mm}$.

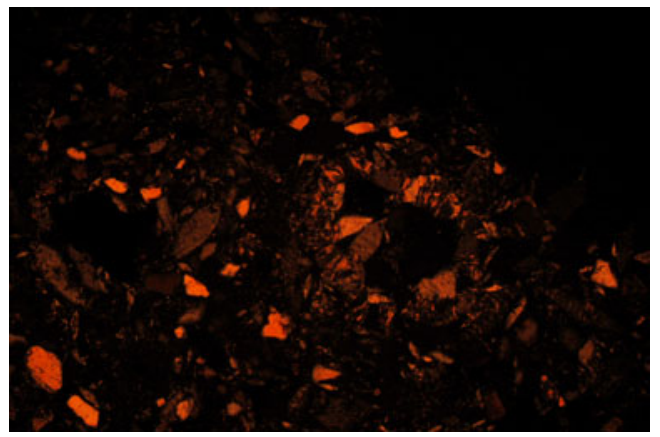

Figure 11. As Figure 10, under crossed polarised light XPL; note coarse silt-very fine quartz sand, and first order birefringent gypsum cement.

Phases 2 and 3 (Figures 24 and 25): The core was rejuvenated and the flaking surface and striking platform prepared for a second preferential Levallois flake removal. The resulting Levallois flake could not be found in the excavated assemblage but from the negative scar left behind it would have been virtually the same shape and size as the first and third Levallois flakes from this cobble.

Phase 4 (Figure 26): All the flakes of the core-preparation stage are present. They indicate that during this phase the flaking surface exhibited distal and lateral convexities, which facilitated control over the size and shape of the Levallois flake. During the removal of this third Levallois flake, the core and the flake broke in two. Figure 27 shows the whole refitted cobble.

In sum, refitting and the analysis of removal scars on the flaking surfaces of the core and the flakes clearly shows that objectives 


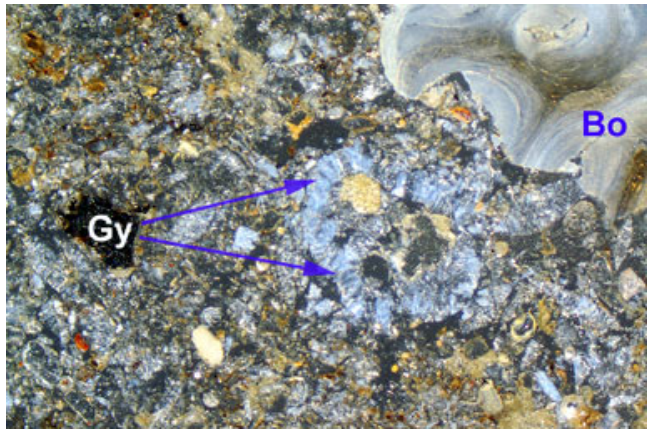

Figure 12. As Figure 10, under OIL; grey burnt bone (Bo) and whitish grey gypsum (Gy).

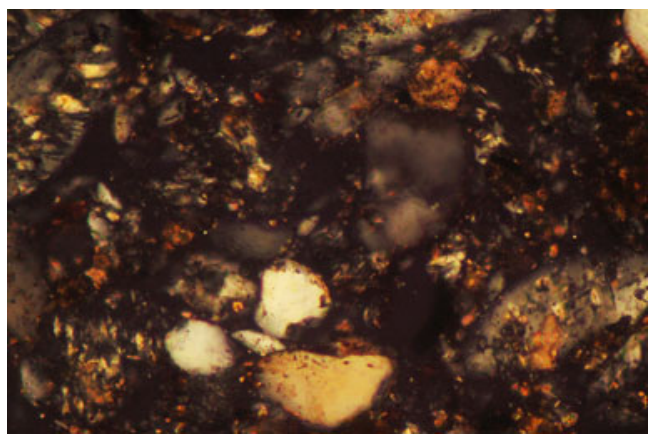

Figure 13. Photomicrograph of OAK-1A; combustion zone with trace amounts of probable strongly birefringent ('bright') calcitic ash crystals scattered throughout. $\mathrm{XPL}$, frame width is $\sim 0.47 \mathrm{~mm}$.

were consistent with the goal of obtaining sub-quadrangular Levallois flakes. Three Levallois flakes were produced from a single cobble, with the refitting showing accidental breakages followed by rejuvenation. Two of these flakes could be refitted to the core while the third was never found and was presumed to have been removed for use somewhere off-site.

\section{Faunal evidence}

Vertebrate remains were identified using osteological collections housed at the Department of Prehistory in the Bardo Museum, Tunis. Each specimen was examined for anthropic and natural taphonomic marks using a binocular microscope. Cut marks were defined as straight, incised grooves displaying a V-shaped cross-section with internal parallel microstriations (Andrews and Cook 1985; Noe-Nygaard 1989; Fisher 1995). Hammerstone percussion marks were identified as being pits and grooves with associated microstriations and lacking internal crushing (Johnson 1985; Blumenschine and Selvaggio 1988; Roberts et al. 2018). Burnt or heated bones were identified by the colour of external surfaces (cf. Brain 1981; Lyman 1994; Stiner et al. 1995). Subaerial weathering was evaluated using the different stages defined by Behrensmeyer (1978). Analysis of bone surfaces for possible weathering and erosion by water action was undertaken using a handheld lens and employing the methods of Lyman (1994) and Isaac (1983).

A total of 219 numbered remains of fauna (NR) was recovered in the excavations. They consisted almost entirely of fragmented mammal bones (196) and teeth (7) plus 16 ostrich eggshell fragments. Of these, five teeth can be broadly identified as bovids and classed according to size (Table 11). Only one of the bones can be identified taxonomically as a phalanx belonging to a $4-5$ bodysize mammal, while the five bovid teeth are from those ranging

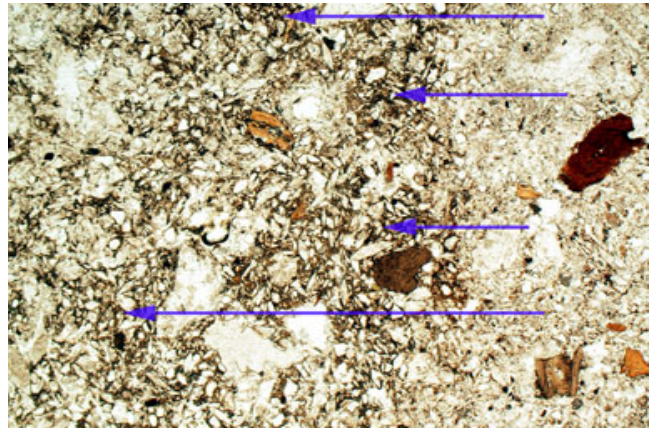

Figure 14. Photomicrograph of $C Z$ in OAK-1B containing fine burnt bone, with broad dark channel fill - gypsum fine sand with isotropic matrix - presumed hydroxlapatite (arrows). PPL, frame width is $\sim 4.62 \mathrm{~mm}$.

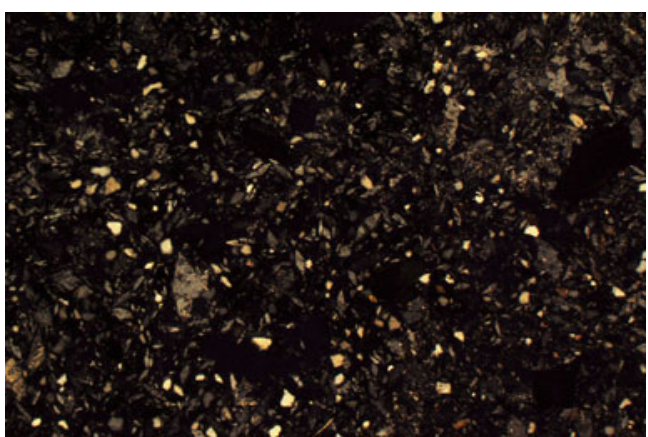

Figure 15. As Fig 14, under XPL; fine feldpsar, quartz and gypsum sands, with isotropic phosphate matrix.

in body sizes from large (size 3, from Bovini group) to small (size $1, c f$. Antilopini group). It is likely that the bigger bone fragments also belonged to a large bovid but this cannot be confidently asserted as they could also be from other large-boned ungulates such as equids or rhinoceros and for the present are classified under 'other mammals' (Table 11). The classificatory system of faunal remains is specific to the present study.

As mentioned above most of the bones were broken and imply intensive fragmentation. Absence of tooth marks or related scavenging damage can be used to rule out the interference of carnivores and only one bone shows traces of dissolution without rounding which could have been due to water percolation. From the condition of the rest of the assemblage it is clear that the bones were not submerged in water for very long, if at all, or dispersed by hydraulic action. Equally, it is noticeable that the surfaces of the large mammal bones exhibit a slight degree of weathering (stages 1-2 in the scheme of Behrensmeyer 1978) (Table 12).

Signs of deliberate human modification are visible from percussion notches on long bones and spiral fracture patterns that imply working on fresh bone (Table 13). Five of the bones reveal distinctive cut-marks (Figures 20 and 21) and one displays prominent scrape marks probably made by a stone tool. It should also be noted that about a fifth of the bones are burnt $(21 \% \mathrm{NR}=203)$. The presence of dry bone fractures on some of the bones, however, suggests that fragmentation arose from diverse processes implying a complex taphonomy. There are insufficient data from the available assemblage to accurately describe the method of butchery but it is clear that bone was probably marrowfractured and, at some stage, some of it burnt; the possible reasons for this are discussed below (see discussion). It is likely that the bones lay exposed on the surface for a relatively short time after the site was abandoned. Their condition indicates a certain 
Table 4. Five Parameter Analyses (M - magnetic susceptibility, MS550, fractionated P, LOI).

\begin{tabular}{|c|c|c|c|c|c|c|c|c|c|c|c|}
\hline $\begin{array}{l}\text { Feature } \\
\text { No }\end{array}$ & Area & Layer & $\begin{array}{l}\text { Field } \\
\text { Note }\end{array}$ & MSIf & MS550lf & MS550hf & $\begin{array}{l}\text { CitP } \\
\mathrm{HCL}\end{array}$ & CitPOI & $\begin{array}{c}\text { CitPOI } \\
\mathrm{HCL}\end{array}$ & $\begin{array}{c}\text { Pquota } \\
\mathrm{HCl}\end{array}$ & LOI \\
\hline 8005 & M5 & $\begin{array}{c}34-43 \mathrm{~cm} \\
\text { below } \\
8005\end{array}$ & & 8 & 8 & 7 & 166 & 417 & 307 & 1.85 & 1.5 \\
\hline 8005 & M5 SE & & $\mathrm{CZ}$ & 54 & 60 & 55 & 3353 & 2647 & 3634 & 1.08 & 6.8 \\
\hline 8003 & M5 SE & mid & & 6 & 6 & 6 & 157 & 364 & 376 & 2.4 & 1.2 \\
\hline 8003 & M5 SE & top & & 11 & 11 & 11 & 257 & 393 & 438 & 1.7 & 1.7 \\
\hline 8002 & M5 SE & mid & & 8 & 8 & 7 & 155 & 266 & 338 & 2.19 & 0.8 \\
\hline 8005 & N5 SE & & $\mathrm{CZ}$ & 54 & 57 & 51 & 943 & 484 & 548 & 0.58 & 1.9 \\
\hline 8005 & P6 NW & & $\begin{array}{c}C Z \\
(\mathrm{M} 1 \mathrm{~A}-1 \mathrm{~B})\end{array}$ & 37 & 43 & 39 & 1940 & 478 & 1086 & 0.56 & 10.1 \\
\hline
\end{tabular}

NB: $C Z$ = combustion zone; If = low frequency; hf = high frequency

Table 5. OSL data for Oued el Akarit (Sondage 8) including radionuclide concentrations determined by ICP-MS, dose rates using the conversion factors of Guerin et al. (2011), palaeodoses and age estimates.

\begin{tabular}{|c|c|c|c|c|c|c|c|c|c|c|}
\hline Sample & $\begin{array}{c}\mathrm{K} \\
(\%)\end{array}$ & $\begin{array}{c}\text { Th } \\
(\mathrm{ppm})\end{array}$ & $\begin{array}{c}\text { U } \\
(p p m)\end{array}$ & $\begin{array}{c}\mathrm{Rb} \\
(\mathrm{ppm})\end{array}$ & $\begin{array}{l}\text { Depth in } \\
\text { Local } \\
\text { Section } \\
(\mathrm{cm})\end{array}$ & $\begin{array}{c}\text { Water } \\
\text { content } \\
(\%)\end{array}$ & $\begin{array}{c}\text { External } \\
\text { Gamma } \\
\text { Dose } \\
\text { Rate* }^{\star} \\
\left(\text { Gy ka }^{-1}\right)\end{array}$ & $\begin{array}{c}\text { Total } \\
\text { Dose Rate } \\
\text { including } \\
\text { cosmic } \\
\left(\text { Gy ka }^{-1}\right)\end{array}$ & $\begin{array}{l}\text { Palaeodose } \\
\left(\text { Gy ka }{ }^{-1}\right)\end{array}$ & $\begin{array}{l}\text { Age } \\
\text { (ka) }\end{array}$ \\
\hline AKR14-06 & 1.07 & 3.6 & 1.2 & 34 & 238 & $11 \pm 3$ & $0.57 \pm 0.06$ & $1.59 \pm 0.07$ & $59.48 \pm 1.60$ & $37.31 \pm 1.97$ \\
\hline AKR14-07 & 0.51 & 1.8 & 0.6 & 16 & 192 & $11 \pm 3$ & $0.35 \pm 0.03$ & $0.89 \pm 0.04$ & $33.31 \pm 1.51$ & $37.29 \pm 2.50$ \\
\hline AKR14-08 & 0.51 & 1.9 & 0.6 & 17 & 148 & $12 \pm 3$ & - & $0.84 \pm 0.03$ & $31.75 \pm 2.95$ & $37.69 \pm 3.78$ \\
\hline
\end{tabular}

*Determined on site with a portable gamma-ray spectrometer calibrated against the Oxford blocks. Source: Rhodes and Schwenninger (2007).

amount of weathering and there is some bone diagenesis caused by sediment cemented to the bone (gangue) and minor breakage might have resulted from subsequent sediment loading or due to later root action.

Finally, it can be noted that there are no bones or teeth of carnivores in the assemblage, nor are there any signs of carnivore or rodent damage to any of the bones. Given the above-mentioned results it appears that, despite dry bone breakage and some diagenetic alteration, modification due to human activities is clearly indicated.

\section{Discussion and conclusions}

The site of Oued el Akarit (Sondage 8) was first reported by Page (1972) as one of a number of stratified archaeological occurrences exposed by later down-cutting of the wadi and side gullies. The area around Akarit is also marked by a series of natural artesian springs, coincident with the junction of two geological fault zones, and which provide reliable water sources even today for the nearby modern settlement. The archaeological unit (EU 8005/6) is the equivalent of Page's 'upper archaeological horizon', while his 'lower horizon' can be identified with one of a number of MSA cultural units that lay beneath this and can be traced in neighbouring exposures. Interestingly, the second dated horizon discovered in our survey (S8-A see Table 6) lies at a much lower elevation than Page's lower horizon and reaffirms the important sequence of MSA deposits exposed in this part of the wadi.

The excavation of S8 EU 8005/6 revealed a once very extensive concentration of archaeological and faunal finds associated with a dark band of organic-rich sediments. The area of activity lay on a slightly raised, and relatively stable, land surface. We interpret EU $8005 / 6$ as the remnants of one or more 'lightly' trampled occupation surfaces, perhaps fitting the description of micro-palimpsests representing diffuse formation interrupted by small-scale abandonment episodes, possibly including a little wind deflation and/or washing but not involving bulk erosion. The micromorphological thin section evidence reveals very abundant burnt bone but generally only trace amounts of fine charcoal, burnt mineral and calcitic ash. The presence of these remnants may partly be attributed to taphonomic effects (leaching and wind winnowing). The dark-colour of the sediments is probably due mainly to natural small-scale biological activity (insect burrows and plant rooting) following and even promoted by human occupation presence. Although no humanly-built structures were uncovered in the restricted area excavated, the concentrations of phosphate (550-3630 ppmP) and organic matter (max 10.1\%), and an enhanced magnetic susceptibility (in low frequency mass specific terms, 37-54.1f $10^{-8} \mathrm{~m}^{3} \mathrm{~kg}^{-1}$ ), are all consistent with burning as would be expected if hearths had been present nearby.

A noteworthy occurrence is the concentrations of secondary phosphate - possibly from guano-rich deposition - in EU 8002 and EU 8003 (above the archaeological layer). Why birds would have congregated at this particular point in the landscape is not easily explicable. For example, there is no evidence for nearby tree roosting locations (such as major rooting systems of large trees or tree fall hollows) or significant 'cliffs' in the sediments near the site. Instead, one possibility is that large flocks of migrating birds may have been attracted by local bodies of standing water. If this was followed by phases when the water bodies 


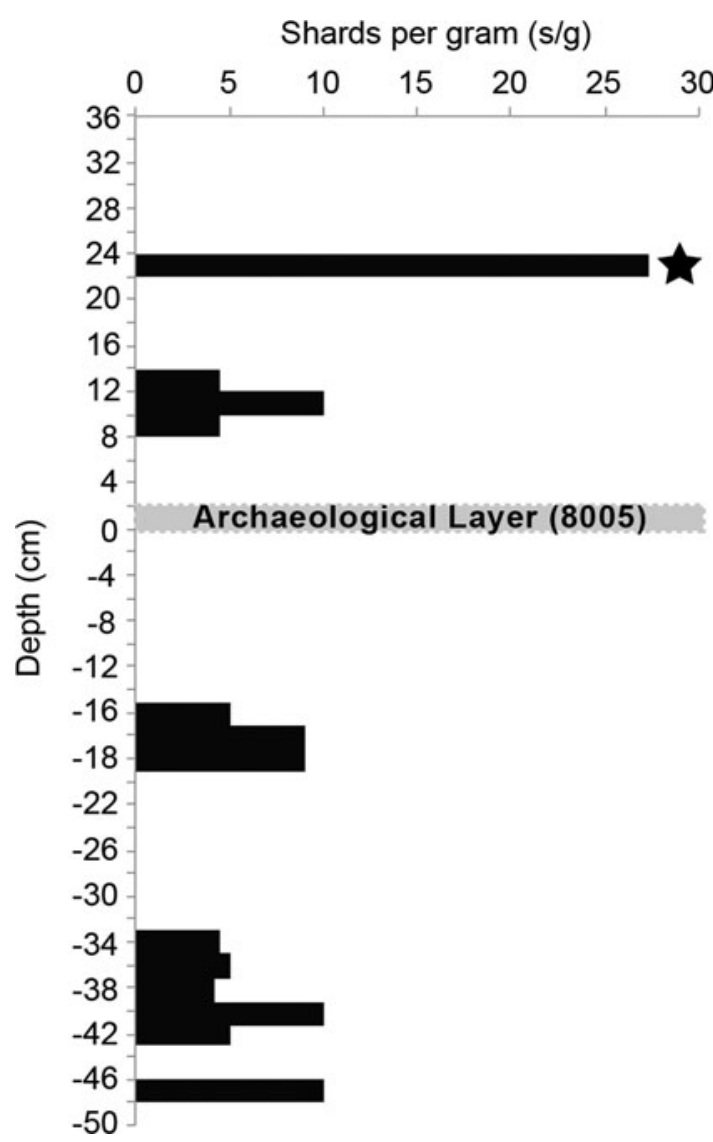

Figure 16. Glass shard concentrations (shards per gram of dry sediment) vertically through the sequence that contains the archaeological finds. A horizon with a concentration of glass shards ( $\sim 27 \mathrm{~s} / \mathrm{g}$; marked by a black star) was identified in the sample taken $22-24 \mathrm{~cm}$ above the archaeological finds sub-units (EU 8005/6). Shards from this layer were chemically analysed but the volcanic source is not yet known. dried out, any guano-rich crusts could have been converted to finer sand and then distributed by wind quite widely and uniformly across the neighbouring landscape. Clearly, this is only a hypothesis at present but it would be interesting to explore in the future whether this particular pattern (human occupation overprinted by apparent guano enrichment) were repeated at other locations along the valley, possibly serving as a subtle marker of fluctuating humid-followed-by-drier climatic conditions at least at a local level.

Spatial analysis of the archaeological finds has shown that the scatter of material covers an area of at least $9.4 \mathrm{~m}^{2}$. The finds are dominated by lithic artefacts which occur in all of the fully and partially excavated squares. Relatively low densities of faunal remains (219) were recovered in relation to the lithic artefacts (541). Like the lithics, the mostly fragmentary bones are scattered across the whole exposed surface and include rare fragments of ostrich eggshell (16) in squares O6, N5 and M5 (Figure 22). Figure 19 shows the distribution of lithic artefacts according to their different techno-typological features.

In terms of human activities, the main focus seems to have been on the manufacture and use of lithic tools associated with the processing of large ungulates. Based on the positive identification of the teeth, the faunal assemblage would have included a number of large-sized bovids. Many of the bones were highly fragmented and appear to have resulted from a combination of human modification and natural taphonomic processes. From information recorded on the orientation and dip of the bones, there is no indication of hydraulic transport, nor do the bones seem to have been disturbed by carnivore activity (absence of scavenging marks and related damage). The fact that the bones included cut-marked examples and broken fragments with spiral fractures and percussion marks suggests that animal carcasses were freshly butchered and the bones probably smashed for the extraction of marrow. Other pieces of 'dry' fractured bone might have been a consequence of subsequent treadage or sediment loading and is consistent with the idea that site comprised

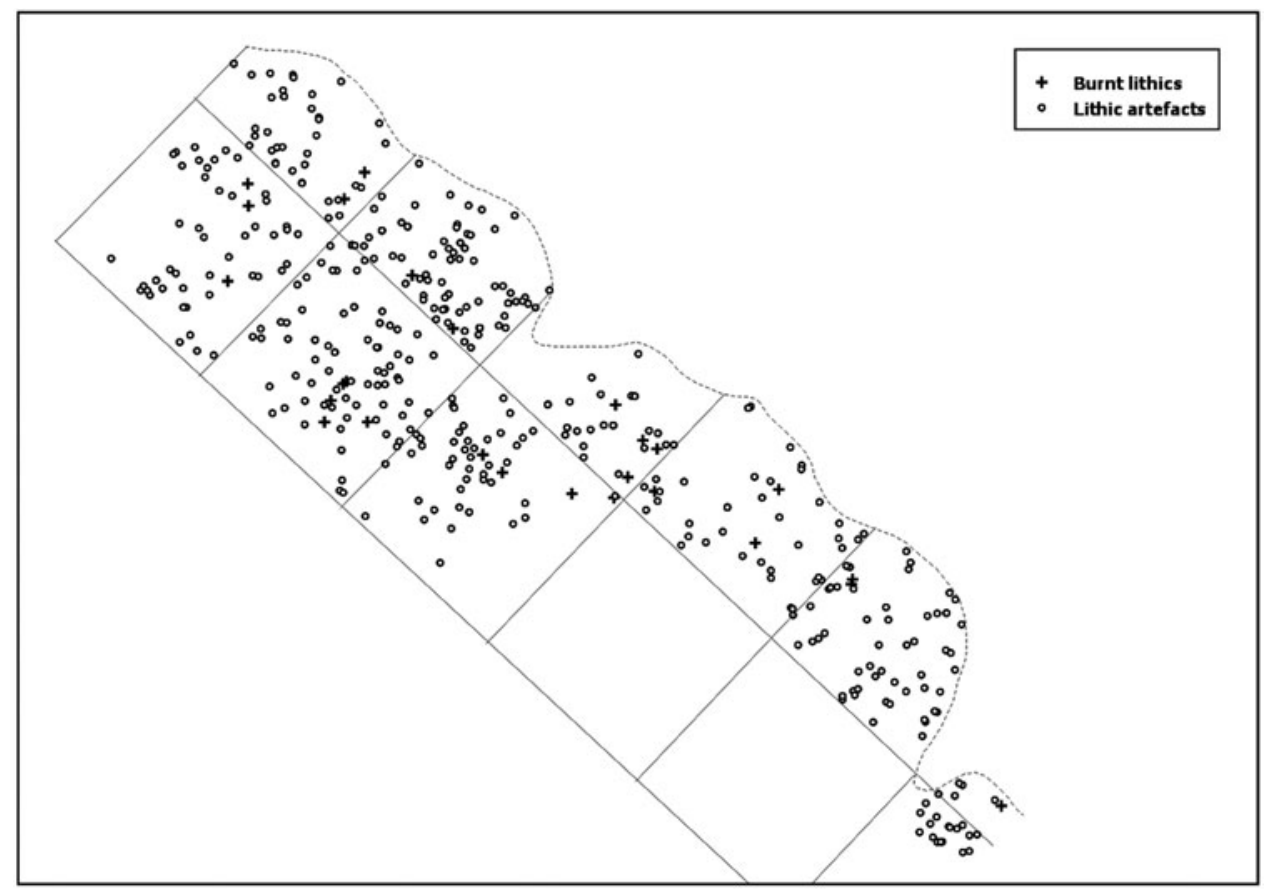

Figure 17. Distribution of artefacts (burnt vs unburnt) in S8. 
Table 6. AMS ${ }^{14} \mathrm{C}$ data for Oued el Akarit (Sondage 8 and 8-A).

\begin{tabular}{|c|c|c|c|c|c|c|}
\hline ORAU lab code & $\begin{array}{c}\text { Conventional }{ }^{14} \mathrm{C} \\
\text { age BP } \\
( \pm 1 \sigma)\end{array}$ & $\begin{array}{c}\text { Calibrated age (cal BP) } \\
95.4 \% \text { range }\end{array}$ & Unit & Species & $\delta^{13} \mathrm{C}$ & $<$ OAK Ref $>$ \\
\hline OxA-33204 & $39,550 \pm 400$ & $44100-42650$ & EU 8006 & Struthio sp. & -7.08 & OAK15-108 \\
\hline OxA-33205 & $47,200 \pm 800$ & $>49950$ & $\mathrm{~S}-8(\mathrm{~A})$ & Struthio sp. & -9.11 & OAK15-9030 \\
\hline
\end{tabular}

Table 7. Lithic debitage from S8 (based on the classificatory system of Geneste 1985).

\begin{tabular}{|c|c|c|}
\hline & Type & Number \\
\hline \multirow[t]{4}{*}{ Cores } & Levallois cores & 14 \\
\hline & Fragments of Levallois cores & 2 \\
\hline & Cores on a flake & 2 \\
\hline & Unidentifiable core type & 1 \\
\hline \multirow[t]{3}{*}{ Cortical flakes } & $100 \%-51 \%$ cortex on dorsal surface & 22 \\
\hline & $\leq 50 \%$ cortex on dorsal surface & 58 \\
\hline & Naturally backed knife & 16 \\
\hline \multirow[t]{8}{*}{ Flakes } & Levallois & 16 \\
\hline & Atypical Levallois & 1 \\
\hline & $\begin{array}{l}\text { Simple flakes and rejuvenation } \\
\text { flakes }\end{array}$ & 63 \\
\hline & Edge removal flakes & 17 \\
\hline & Simple blades & 4 \\
\hline & $\begin{array}{l}\text { Small flakes and fragments between } \\
5-20 \mathrm{~mm}\end{array}$ & 92 \\
\hline & Flake fragments without cortex & 24 \\
\hline & Retouch flakes & 8 \\
\hline \multirow{2}{*}{$\begin{array}{l}\text { Other debris } \\
\text { (shatter) }\end{array}$} & $>20 \mathrm{~mm}$ & 37 \\
\hline & $<20 \mathrm{~mm}$ & 139 \\
\hline TOTAL & & 516 \\
\hline
\end{tabular}

Table 8. Retouched tool typology.

\begin{tabular}{lc}
\hline Tools & Number \\
\hline Side scrapers & 18 \\
\hline Raclette & 2 \\
\hline Mousterian point & 1 \\
\hline Notch & 1 \\
\hline Denticulate & 1 \\
\hline Backed knife & 1 \\
\hline Composite tool & 1 \\
\hline TOTAL & 25 \\
\hline
\end{tabular}

a palimpsest of activities, perhaps not greatly separated in time. The most likely explanation for the presence of burnt bone and flints is that they were connected with activities around a hearth. It is possible that the burnt bone was a by-product of meat roasting or subsequent waste disposal or evenits use for fuel. Alternatively, similar actions have been described ethnographically for preparing bones for marrow fracture though this did not normally entail more than lightly heating the bone (e.g. Gifford-Gonzalez 1989). In summary, it appears that the bones were subject to a number of human processes beginning with butchery and marrow breakage and probably ending with burning.

Evidence for in situ flint artefact production comes from the spatial co-occurrence of Levallois flakes and cores, especially in squares Q5, Q6 and P5, with a concentration of six cores in

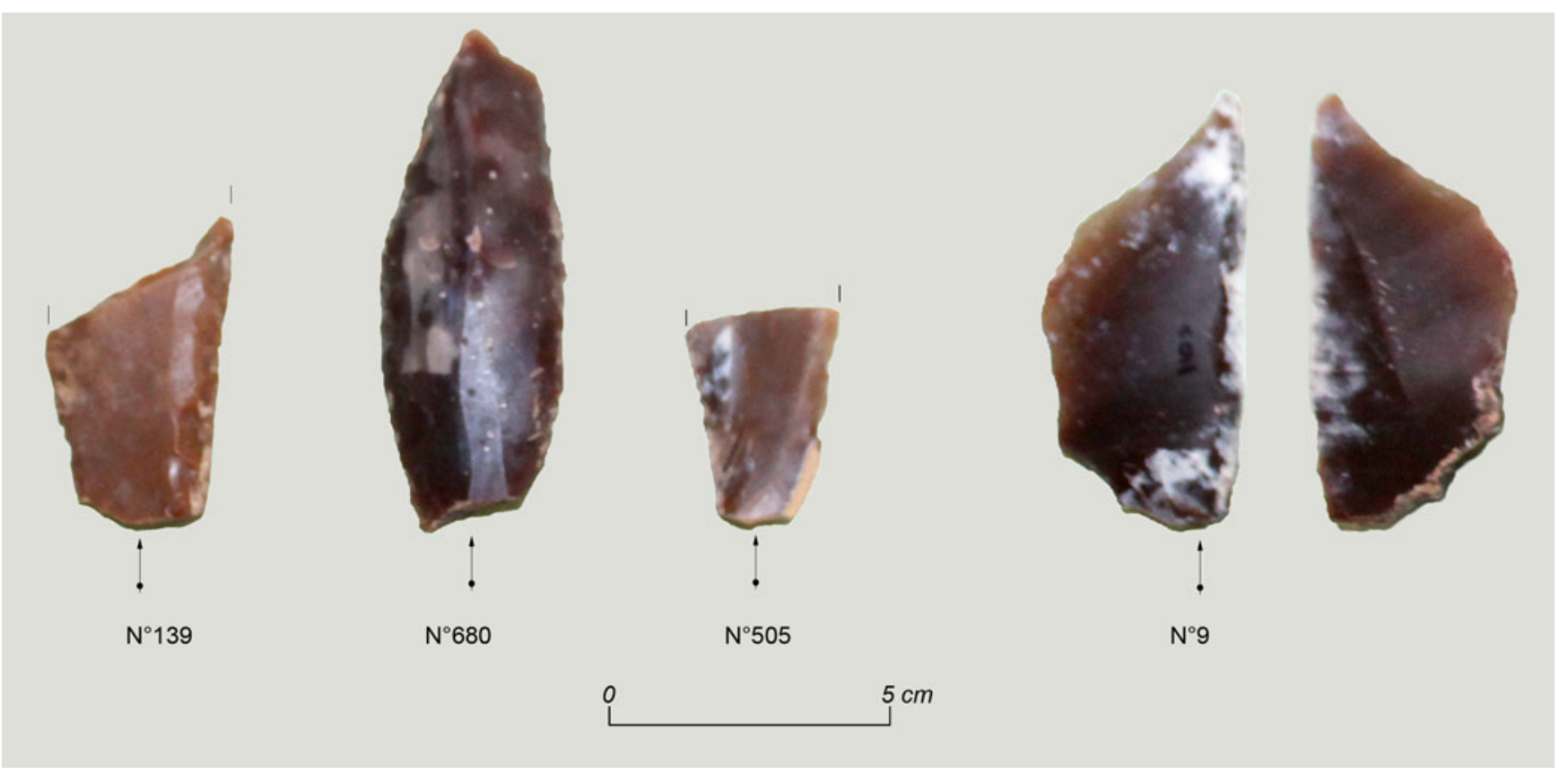

Figure 18. Side scrapers from S8. 139: single side scraper (broken); 680: double side scraper; 505: single side scraper (broken); 9: ventrally (inverse) retouched side scraper. (Photo: L. Belhouchet). 


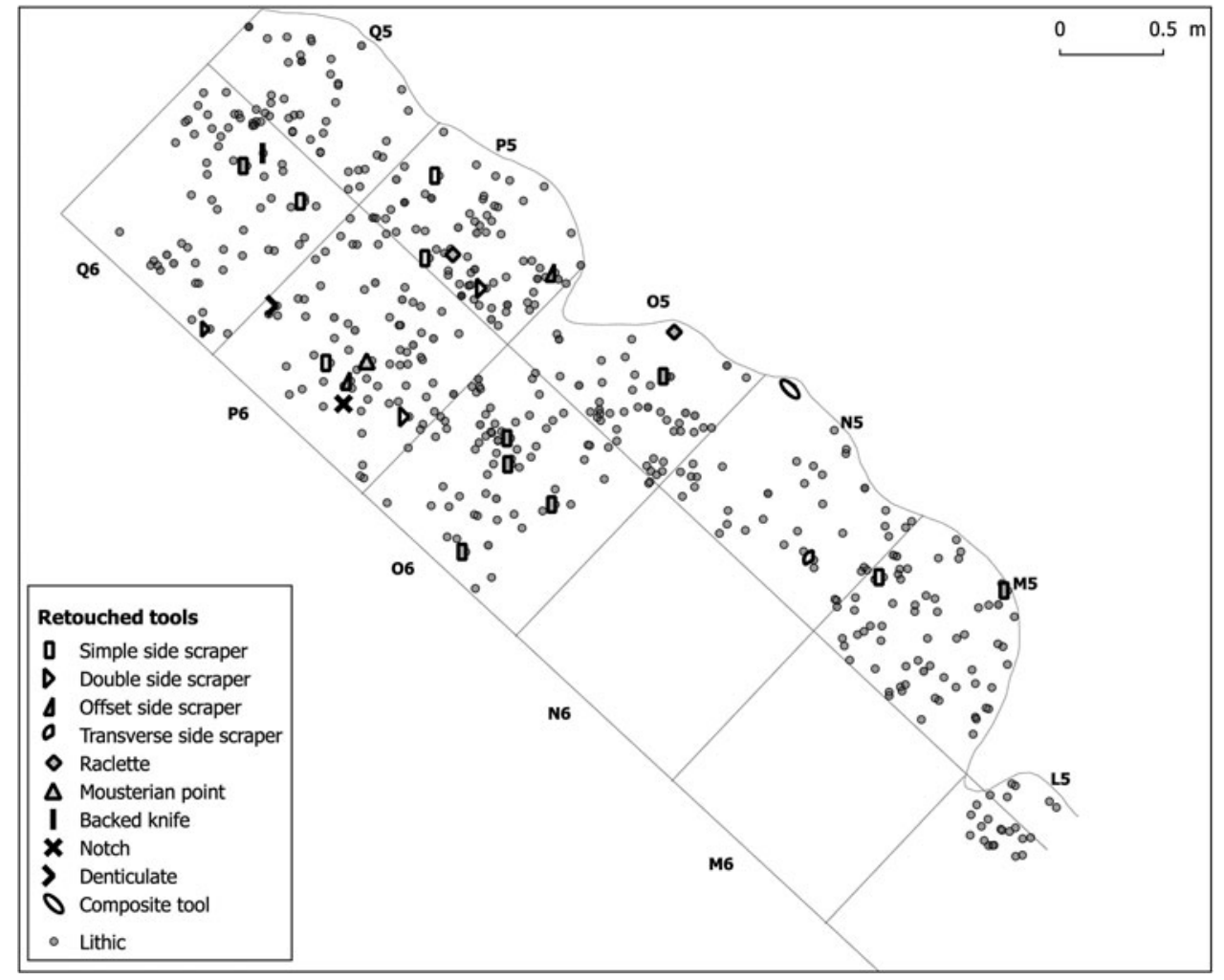

Figure 19. Distribution of retouched tools in S8 (H. Mekki).

square Q6. The relative proportion of Levallois flakes (6\% of the flake total) to Levallois cores is nevertheless quite low, and implies that a number of the flakes were probably removed from the site. The six retouched tools on Levallois products further suggests that any 'missing' pieces in the refits probably represent tools (such as scrapers) that were removed for use elsewhere. The refitting of lithic artefacts also provides an interesting insight both into knapping techniques and raw material behaviour of MSA humans. The flaked materials, of good quality Cretaceous and Eocene flints, were probably all from local sources within $5 \mathrm{~km}$ of the site. Whole raw cobbles were evidently carried to S8, rather than being prepared elsewhere, and were knapped using mainly hard hammers. At least one of the cobbles produced three sub-quadrangular Levallois flakes that were probably intended as blanks for side scrapers or other tools, and one of which (unbroken?) was removed for use beyond the currently excavated area (perhaps off-site). The majority of retouched tools recovered were side-scrapers (18) and imply a likely emphasis on hide-working in this area of the site or the presence of a more general tool-kit used for skinning, jointing and filleting animal carcasses. Significantly, the lithic refits provide further evidence that the occupation area had not been greatly disturbed and, even if the flints were exposed initially, they would not have lain on the surface for very long. The occurrence of ostrich eggshell, some of it burnt, does not appear to have been connected to activities such as beadmaking. Although not heavily represented, it is possible that eggs of these large birds were exploited for their nutritional value and/or use as water containers. Thus, S8 seems to have been a foraging camp probably used only briefly or revisited at short intervals over a limited period.

The age of the assemblage in S8 is based on two independent dating methods. OSL age determinations from just above and below the archaeological horizon of $37.3 \pm 2.0$ to $37.3 \pm 2.5 \mathrm{ka}$
BP years are slightly younger than the direct AMS date of $39,550 \pm 400 \mathrm{BP}(44,100-42,650 \mathrm{cal} \mathrm{BP})$ on ostrich eggshell from the cultural horizon. These dates and that of the underlying occupation horizon (S8-A) reflect part of a long history of human activity in the equivalent of MIS (Marine Isotope Stage) 3, a period of fluctuating humid-dry conditions that preceded a major phase of aridity in the Sahara. In passing it should be noted that the AMS date is similar in age to a period of intense volcanic activity characterised by the Campanian Ignimbrite eruption on the Italian peninsula that produced ash distribution extending as far as North Africa (Barton et al. 2015). Unfortunately, despite several attempts it has not been possible to robustly geochemically characterise the cryptotephra shards preserved in the Sondage 8 deposits so this correlation is yet to be confirmed.

Seen in its broader context, the new work at Akarit S8 is just one of a number of recent fieldwork projects focusing on the the nature and extent of human occupation in Tunisia during the Upper Pleistocene (Roset and Harbi-Riahi 2007; Aouadi-Abdeljaouad and Belhouchet 2008, 2012; Di Lernia et al. 2017). The few sites with preserved stratigraphy that have so far been dated are mainly identified with MSA Aterian tanged point assemblages. These include Nefta towards the western end of the Chotts megalake (Figure 1), where stemmed Aterian points have been found along what Drake et al. (forthcoming) interpret as the former lake margin, in sediments with an estimated OSL age of between 72,000 to 98,000 years ago. Earlier excavations at Aïn El Guettar (Aouadi-Abdeljaouad and Belhouchet 2008, 2012) (Figure 1), located a multi-layered site with deposits containing Aterian artefacts lying well below stratified examples of denser 'Mousterian' occupation. The Aterian material includes tanged points and very small centripetal Levallois 'micro' cores; the overlying occupation horizons, in contrast, contain larger flakes and Levallois cores with Mousterian points and side scrapers but, significantly, no tanged artefacts. OSL and AMS dating 

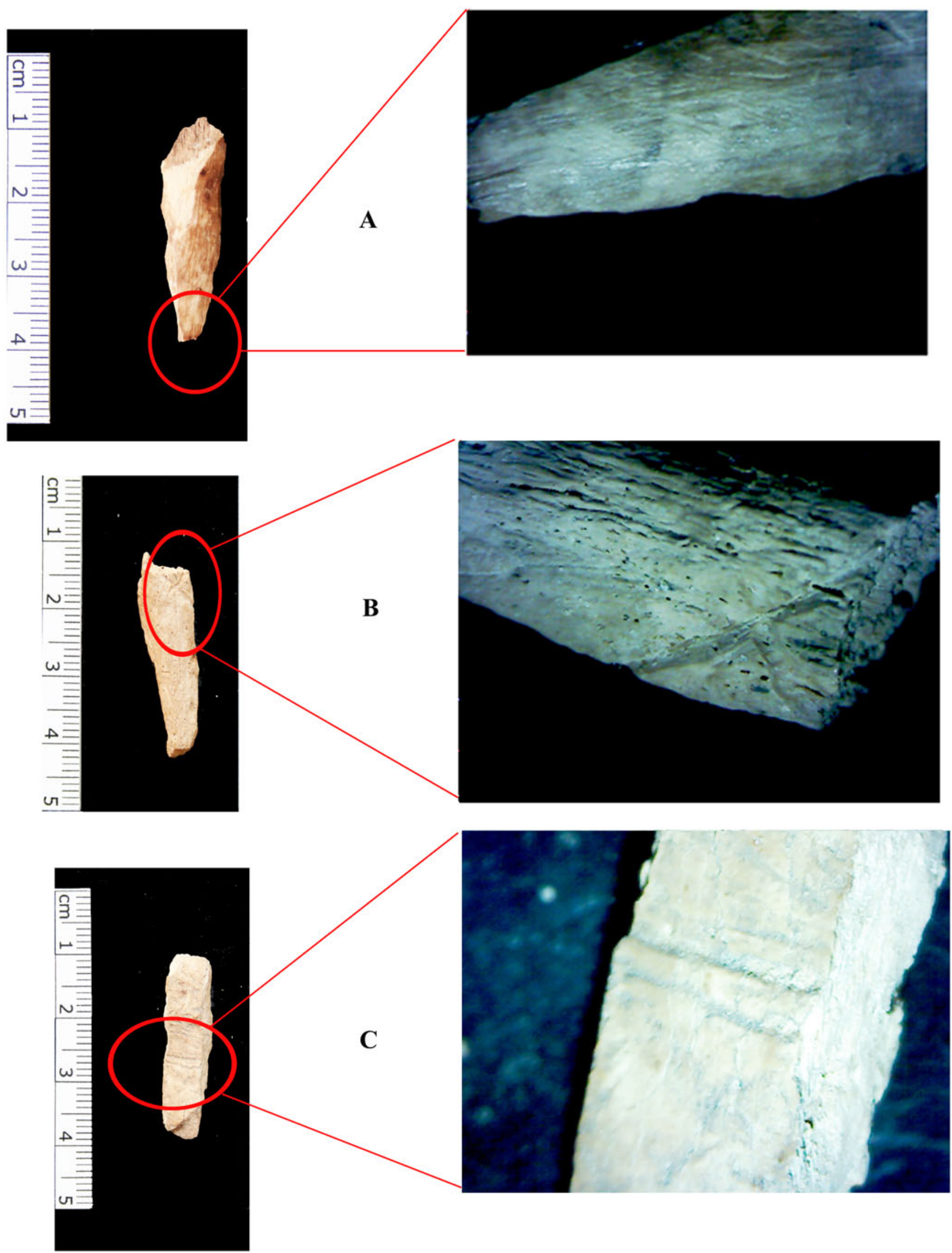

Figure 20. Cut marked bones from S8 (Photos: N. Aouadi): a) Polished end of a bone splinter (OAK/S8/349); b) cut mark that runs obliquely to the long axis of the splinter (OAK/S8/571); c) bone splinter with multiple parallel grooves (OAK/S8/ 8059). 

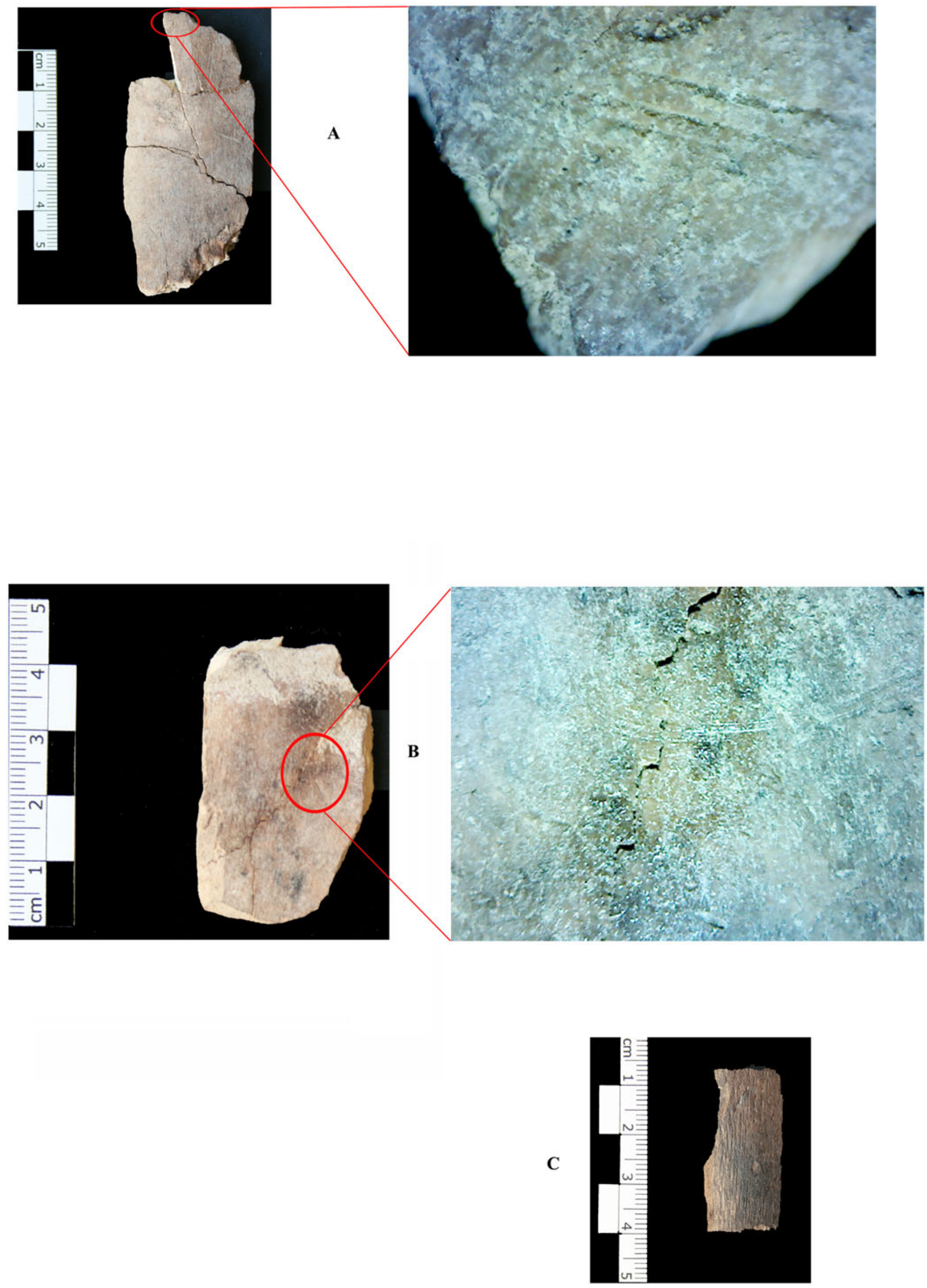

Figure 21. Cut marked bones from S8: a) Cut marks that run obliquely to the long axis of a bone splinter (OAK/S8/8113); b) grooves running wavy and perpendicular to the long axis of a bone splinter (OAK/S8/8066); c) burnt bone splinter (OAK/S8/311). 


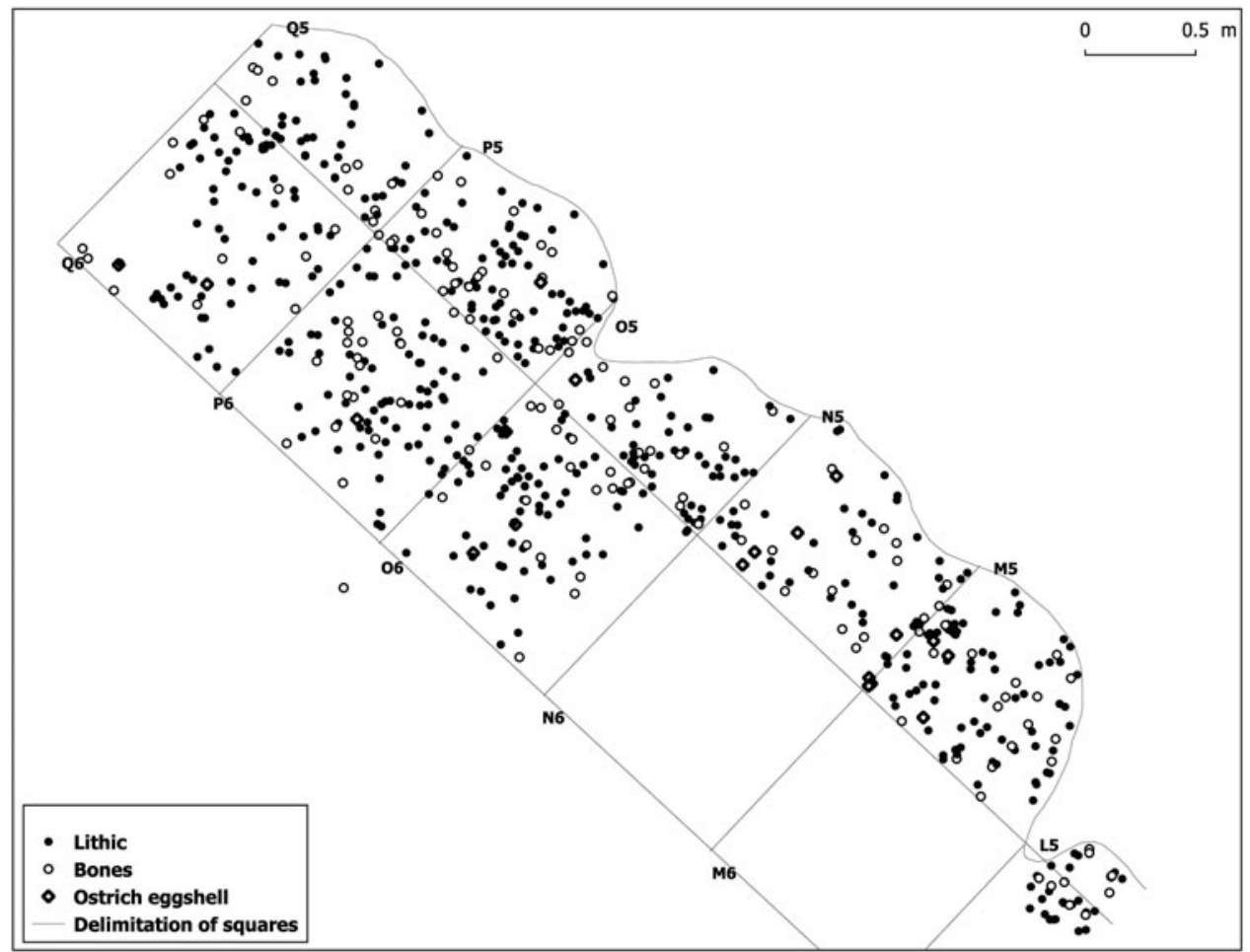

Figure 22. Distribution of lithic artefacts, bones and ostrich eggshell in S8 (H. Mekki).

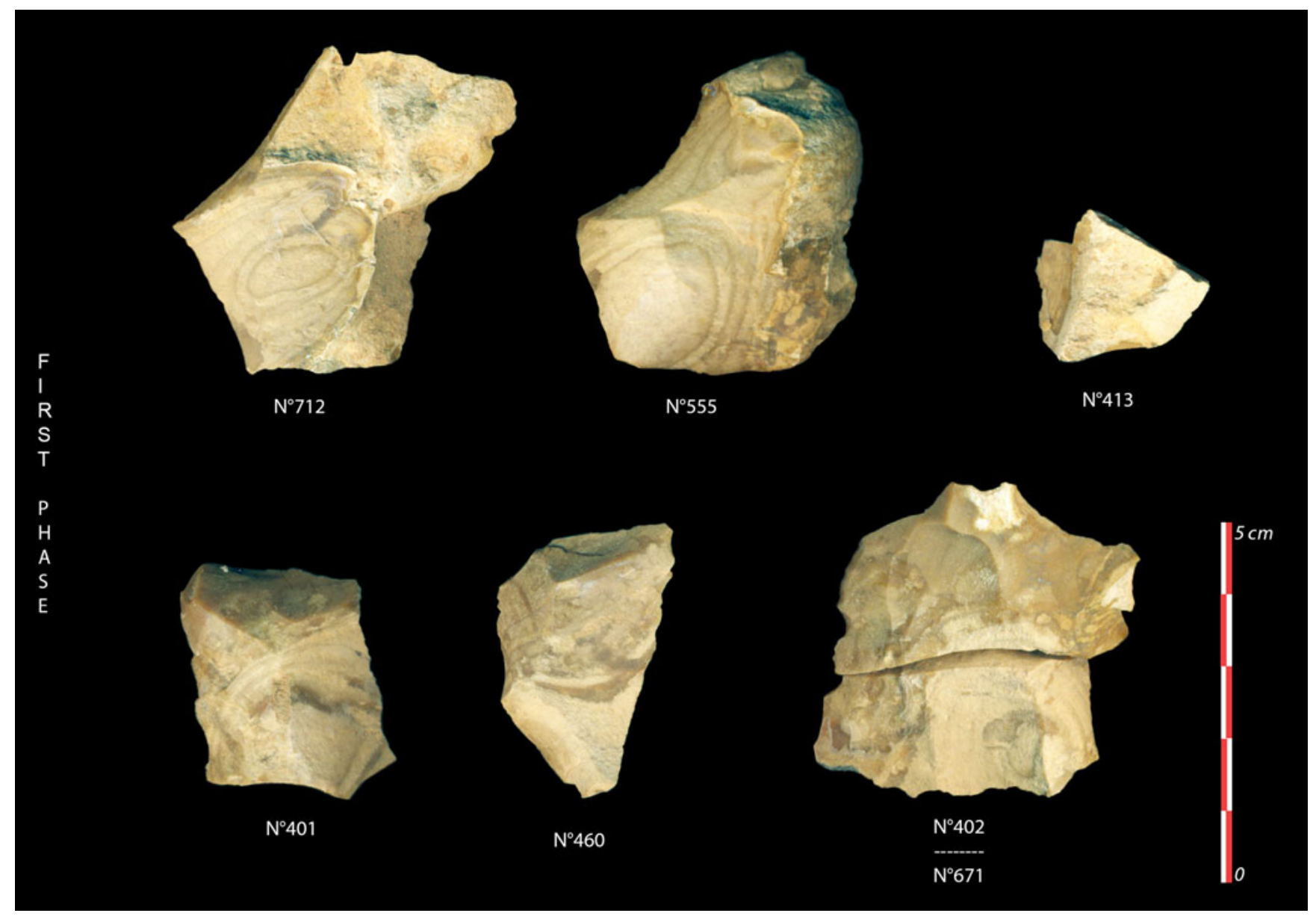

Figure 23. Refitting from Phase 1 (Photo: H. Mekki). 


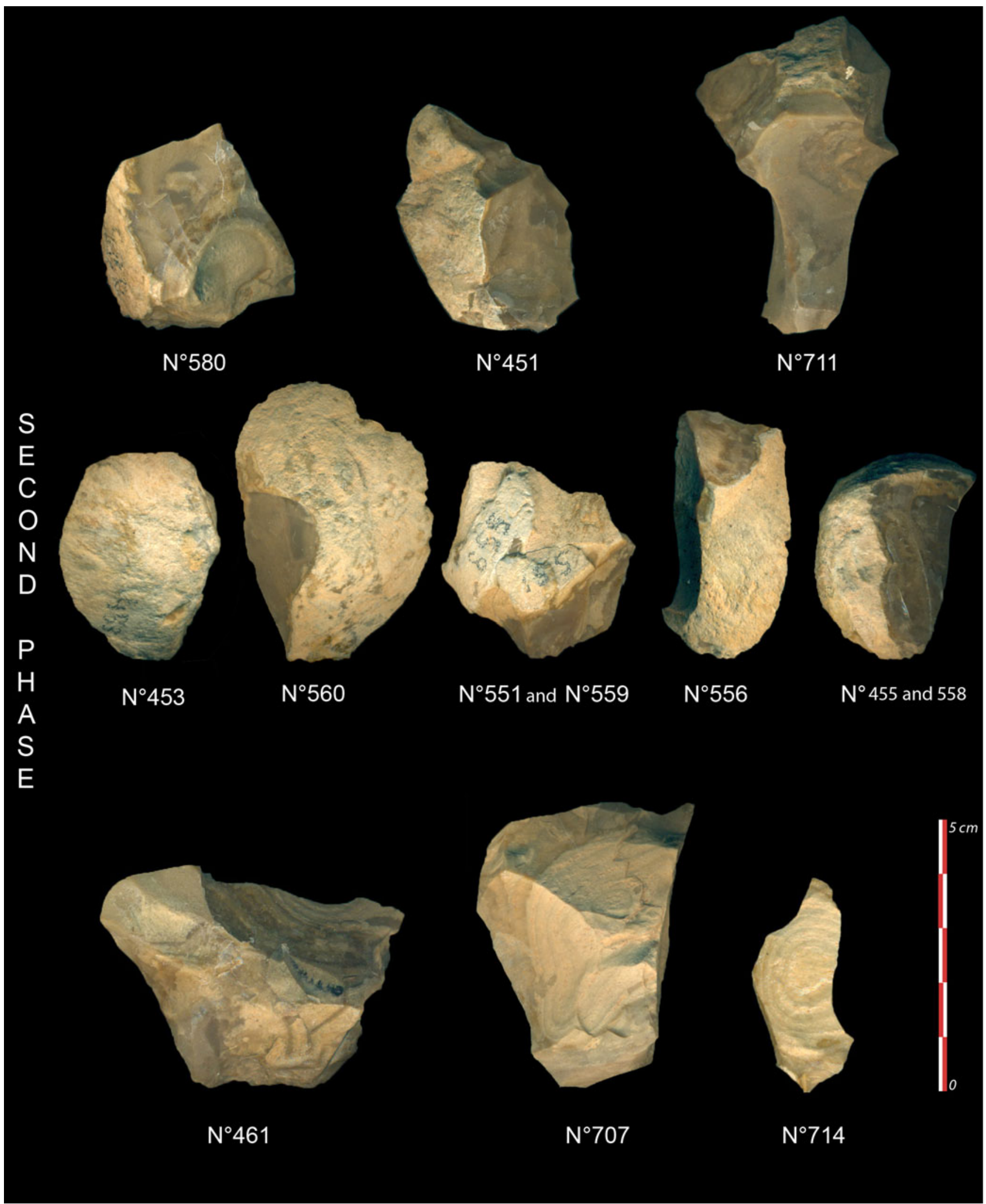

Figure 24. Refitting from Phase 2 (Photo: L. Belhouchet).

of these layers, currently in progress, suggests that the upper archaeological assemblages may compare broadly in age to Akarit (S8). In contrast, earlier excavations at Akarit in 1991-1998 but at an elevation closer to the present valley floor, uncovered a lithic assemblage (niveau 1) which comprised many edge-damaged flints with a high proportion of centripetal Levallois cores, including 'micro' cores (Roset and Harbi-Riahi 2007, planches XVII, 2, XVIII, 3) but no convincing examples of tanged points. Recent re-examination of this location by the present team showed the context to be that of heavily contorted, rotated and down-faulted sediments which complicates interpretation of this context and may explain the severe edge-damage on many of 

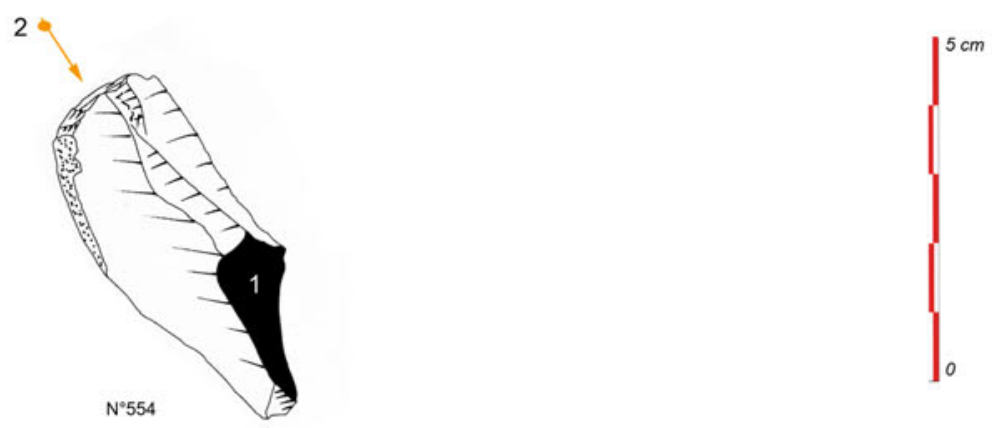

$\mathrm{T}$
$\mathrm{H}$
$\mathrm{I}$
$\mathrm{R}$
$\mathrm{D}$
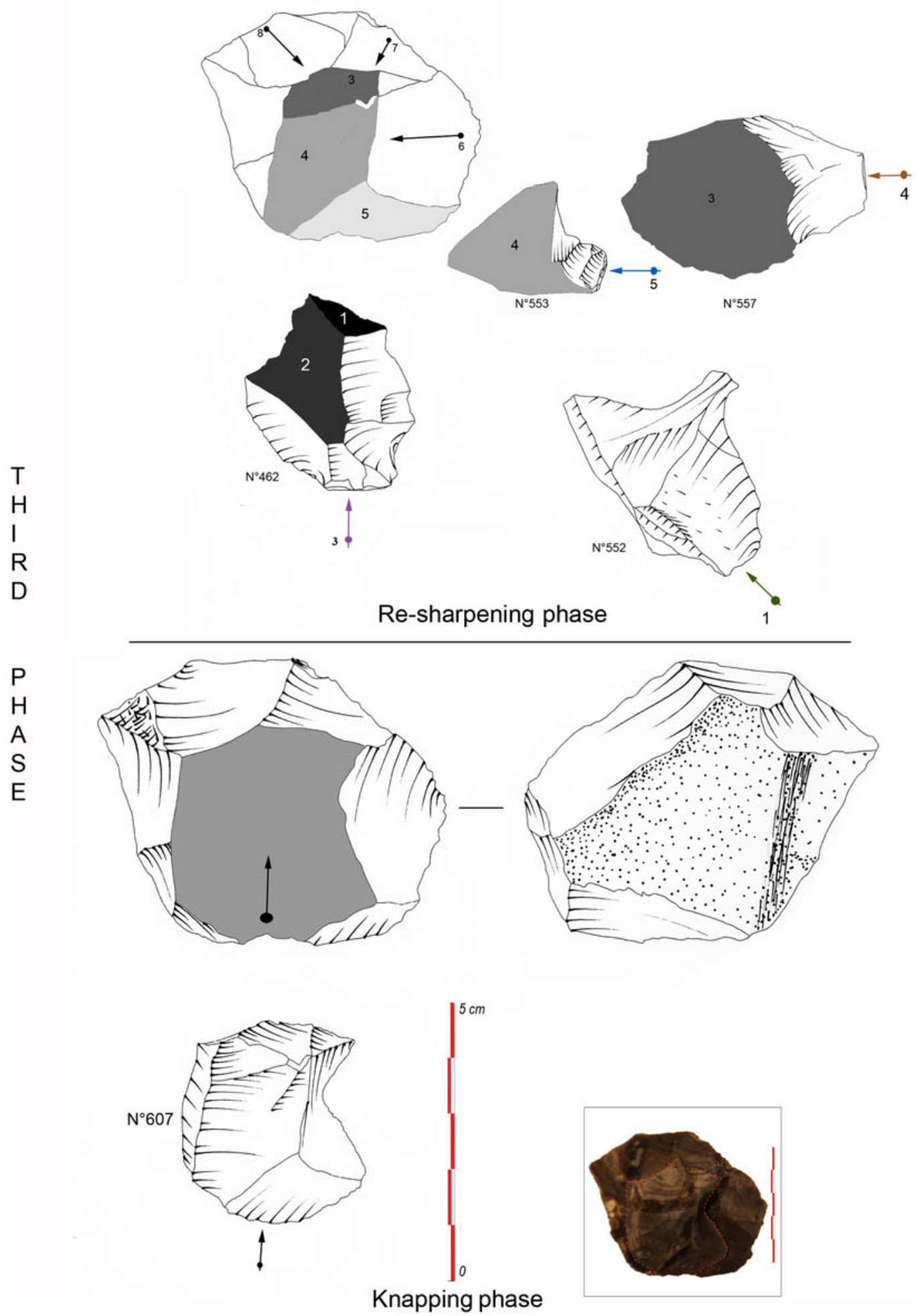

Figure 25. Refitting from Phase 3 (L. Belhouchet) 
Table 9. Average dimensions of flakes from the refitted Levallois core.

\begin{tabular}{lccc}
\hline & $\begin{array}{c}\text { Length } \\
(\mathrm{mm})\end{array}$ & $\begin{array}{c}\text { Width } \\
(\mathrm{mm})\end{array}$ & $\begin{array}{c}\text { Thickness } \\
(\mathrm{mm})\end{array}$ \\
\hline Cortical flakes & 44.3 & 33.8 & 11.9 \\
\hline $\begin{array}{l}\text { Non-cortical } \\
\text { flakes }\end{array}$ & 40.8 & 32.8 & 9.3 \\
\hline Levallois flakes & 40 & 37 & 6.5 \\
\hline
\end{tabular}

Table 10. Butt types of flakes in the refitting core.

\begin{tabular}{lcccccc}
\hline & \multicolumn{5}{c}{ Butt type } \\
\cline { 2 - 6 } & Plain & Cortical & Faceted & $\begin{array}{c}\text { Dihedral } \\
\text { Faceted }\end{array}$ & Other \\
\hline Cortical flakes & 3 & 2 & 8 & 1 & 2 \\
\hline Non-cortical flakes & 2 & - & 5 & 2 & - \\
\hline Levallois flakes & - & - & 2 & & - \\
\hline
\end{tabular}
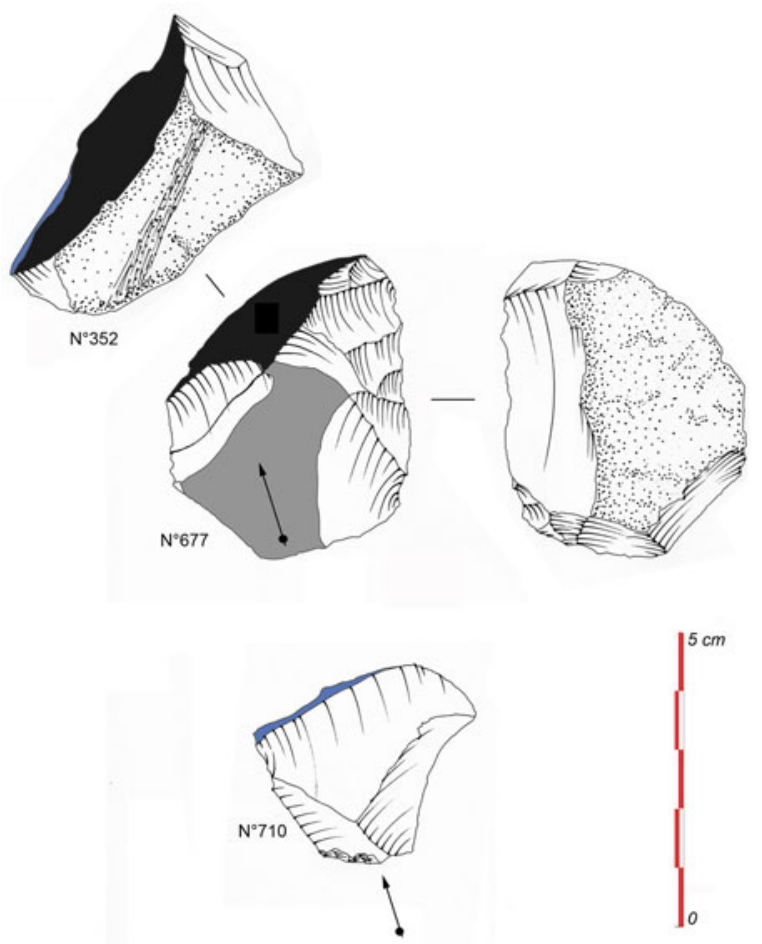

FOURTH PHASE

Figure 26. Refitting from Phase 4 (L. Belhouchet).

the flints. Burnt lithics from niveau 1 had previously yielded a number of widely ranging but unconstrained thermoluminescence ages often quoted as older than 80,000 years (Roset and Harbi-Riahi 2007, 360). The dating and taphonomy of this site (Akarit (S1) in our terminology) and others including the original 'Gobert site' (our S2) are currently under review as part of the present project. It is interesting here to add that in a recent paper by Bahra et al. (2020) attention has been drawn to the distribution of MSA sites (some Aterian) in eastern Algeria where, as in the Tunisian examples, they were found in the vicinity of the Chotts megalake and freshwater springs. Clearly, access to fresh drinking water must have been an important consideration and is a recurrent feature of these MSA open-air sites.
Table 11. Distribution of mammal remains according to body size classes. (NR: Number of Remains).

\begin{tabular}{lcc}
\hline Fauna & Size Class & NR \\
\hline Bovids & 1 & 1 \\
\hline & $2-3$ & 1 \\
\hline Other Mammals & 3 & 3 \\
\hline & $2-3$ & 6 \\
\hline & $3-4$ & 26 \\
\hline & $4-5$ & 18 \\
\hline Total & $5-6$ & 6 \\
\hline
\end{tabular}

Table 12. Weathering stages with only stages 1-2 (slightly weathered) and 3 (weathered) represented in the S8 assemblage (based on Behrensmeyer's 1978 scale of $0-5)$.

\begin{tabular}{lcc}
\hline Weathering stage & NR & $\%$ \\
\hline Stage 1 & 133 & 67.5 \\
\hline Stage 2 & 63 & 32 \\
\hline Stage 3 & 1 & 0.5 \\
\hline
\end{tabular}

In conclusion, the area around Oued el Akarit displays an extraordinarily dense concentration of MSA sites, which may be partly explained by the presence of persistent freshwater springs. We have suggested that water at the surface would have been available near this location more or less continuously (although not always at exactly the same spots) which may have been especially important during the fluctuating humid-dry conditions of MIS 3 (60-25 ka BP). Archaeological material is not present at every level of the deep Akarit sediment stack and it is reasonable to assume that humans would have left more common traces during the more humid climatic episodes within this stage. The sedimentological evidence cited above supports the idea that S8 and other Akarit sites probably lay alongside marshland habitats and in proximity of very shallow perennial pools. It is likely that such pools would have been freshened and refilled by drinkable water partially derived from nearby artesian sources. The area would therefore have offered productive riparian habitats suitable for collecting edible plants and hunting animal game aggregating at the water's edge. This would have included large ungulates such as bovids which were well-adapted to relatively dry conditions in open scrubland. Judging from the deeply stratified sequences with multiple archaeological occurrences it is evident that hunter-gatherers must have resettled or passed through the area at least episodically over tens of thousands of years.

One of the most significant outcomes of this work is that in provides a secure chronological reference point for the MSA in southern Tunisia. It also demonstrates an impressive longevity of the MSA that extended in this area until at least 37,00040,000 years ago. The presence of humans during periods of fluctuating climatic conditions illustrates the resilience of people living along the northern fringes of the Sahara. It also raises several interesting questions concerning continuity of occupation and whether or not there was a major gap in settlement before the Later Stone Age. We hope that this study will stimulate further work on the chrono-cultural record of this archaeologically rich region. 


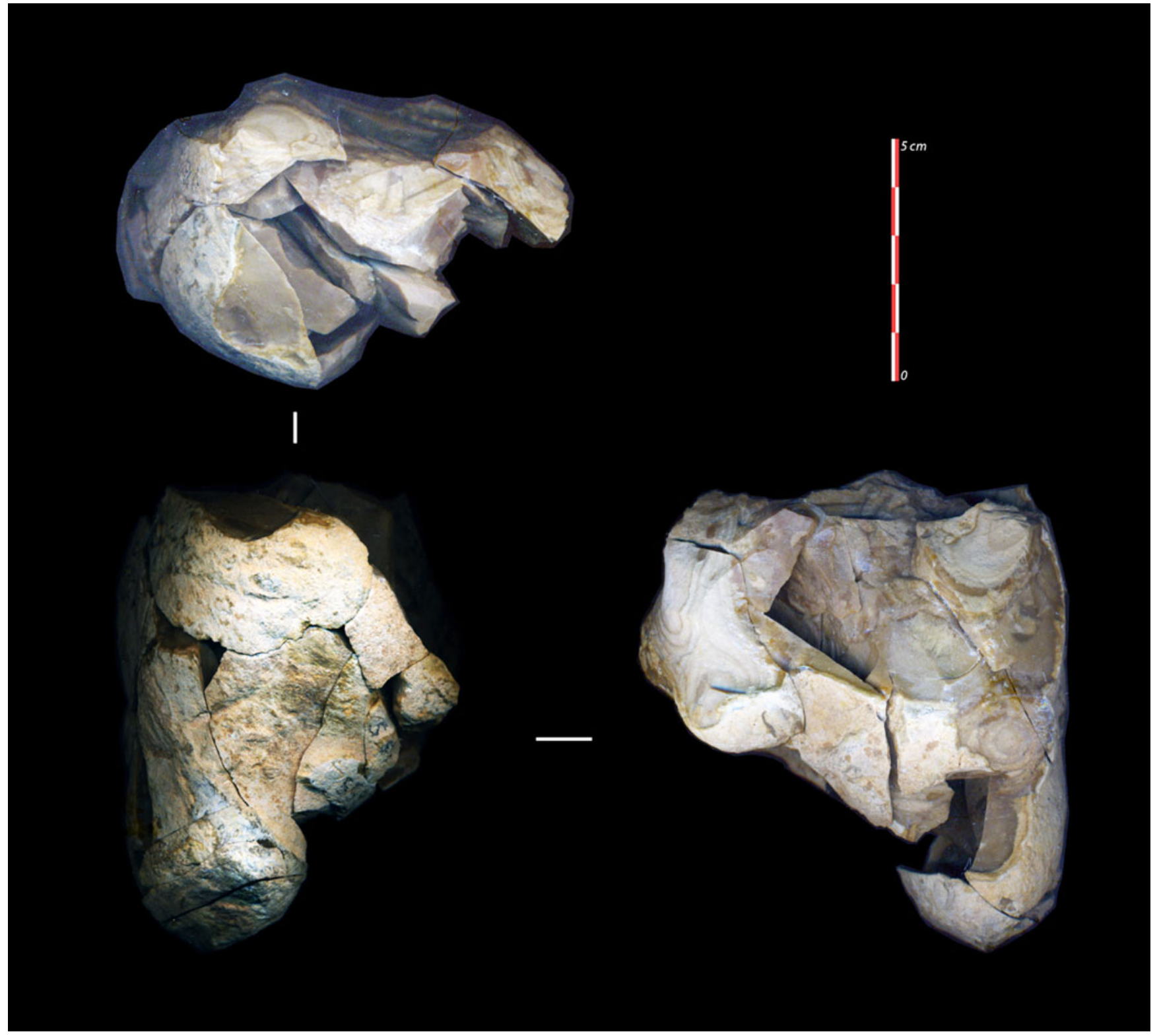

Figure 27. Completed refitting block (Photo: L. Belhouchet).

Table 13. External condition of bones.

\begin{tabular}{lc}
\hline External bone aspect & NR \\
\hline With percussion marks (anthropogenic) & 28 \\
\hline With cut marks (anthropogenic) & 5 \\
\hline Scraped bone (anthropogenic) & 1 \\
\hline With sediment cemented on bone surface & 19 \\
\hline Traces of dissolution & 1 \\
\hline Whitish surface patina & 1 \\
\hline
\end{tabular}

Acknowledgements. This study is part of the ongoing EPoCH CHRON ('Early population of the Chotts and chronology') project organised between the Institut Nationale du Patrimoine de Tunisie and the University of Oxford, UK. We would like to thank the Director General of INP for his personal support and in arranging equipment and personnel for the fieldwork. The Libyan Studies Society also contributed substantially to the costs of fieldwork at S8, as did the Archaeological Museum at Sousse through its director Dr. Lotfi Belhouchet. SNC would also like to thank Dr. William Delano Page for participating in discussion over the general geological context at Oued el
Akarit. The refitting analysis of the lithic artefacts was undertaken by Mekki and Belhouchet. Finally, we owe our gratitude to two reviewers who provided useful comments on an earlier draft of the article.

\section{Notes}

1 Graben: a land block lying between two fault systems and displaced downwards relative to the blocks on either side.

2 Piezometric head: the theoretical height to which water would rise at a particular geographical point, given no change in input or output and unlimited time; the pressures in a system tending towards the theoretical level in real time. 3 Thalweg: the line connecting the lowest points in successive cross-sections of a valley.

\section{Bibliography}

Aitken, M.J. 1998. An Introduction to Optical Dating. Oxford University Press, Oxford.

Andrews, P. and Cook, J. 1985. Natural modifications to bones in a temperate setting. Man 20: 675-691

Aouadi-Abdeljaouad, N. and Belhouchet, L. 2008. Recent prehistoric field research in Central Tunisia: prehistoric occupations in the Meknassy Basin. African Archaeological Review 25: 75-85. 
Aouadi-Abdeljaouad, N. and Belhouchet, L. 2012. Middle Stone Age in Tunisia: present status of knowledge and recent advances. In J.-J. Hublin and S. McPherron (eds) Modern Origins: A North African Perspective. Springer, Dordrecht: 143-155.

Bahra, N., Djerrab, A., Ruault-Djerrab, M., Semiane, K. and Zedam, R. 2020. Middle Stone Age technology in Algeria: a techno-economic approach case study of the Oued Bousmane site (Djebel Dyr). Quaternary International 555: 33-46.

Barton, R.N.E., Lane, C.S., Albert, P.G., White, D., Collcutt, S.N., Bouzouggar, A., Ditchfield, P., Farr, L., Oh, A., Ottolini, L., Smith, V.C., Van Peer, P. and Kindermann, K. 2015. The role of cryptotephra in refining the chronology of Late Pleistocene human evolution and cultural change in North Africa. Quaternary Science Reviews 118: 151-169.

Behrensmeyer, A.K. 1978. Taphonomic and ecologic information from bone weathering. Paleobiology 4: 150-162.

Blumenschine, R.J. and Selvaggio, M.M. 1988. Percussion marks on bone surfaces as a new diagnostic of hominid behaviour. Nature 333: 763-765.

Boëda, E. 1994. Le concept Levallois: variabilité des méthodes. Monographie du Centre de Recherches Archéologiques. CNRS: Paris.

Bouzouggar, A. and Barton, R.N.E. 2012. The identity and timing of the Aterian in Morocco. In J.-J. Hublin and S. McPherron (eds) Modern Origins: A North African Perspective. Springer, Dordrecht: 93-105.

Brain C.K. 1981. The Hunters or the Hunted? An Introduction to African Cave Taphonomy. University of Chicago Press, Chicago and London.

Carter, M. R. 1993. Soil Sampling and Methods of Analysis. Lewis Publishers, London.

Castañeda, I.S., Mulltza, S., Scefuss, E., Lopes dos Santos, R.A., Sinninghe Damsté, J.S. and Schouten, S. 2009. Wet phases in the Sahara/Sahel region and human migration patterns in North Africa. Proceedings of the National Academy of Sciences of America 106(48): 20159-20163.

Causse, C., Ghaleb, B., Chkir, N., Zouari, K., Ben Ouezdou, H., and Mamou, A. 2003. Humidity changes in southern Tunisia during the Late Pleistocene inferred from U-Th dating of mollusc shells. Applied Geochemistry 18: 1691-1703.

Clark, A. 1996. Seeing Beneath the Soil: Prospecting Methods in Archaeology. Batsford, London.

Coulthard, T.J., Ramirez, J.A., Barton, N., Rogerson, M. and Brücher, T. 2013. Were rivers flowing across the Sahara during the last Interglacial? Implications for human migration in Africa. PLoS ONE 8(9): e74834.

Di Lernia, S., Anagnostou, P., Ben Fraj, T., Ben Nasr, J., Boukhchim, N., Boussoffara, R., Hedi Bel Haj Brahim, H., et al. 2017. First archaeological investigations in the Chott el Jerid area, Southern Tunisia. Scienze Dell'Antichità 23(1): 3-20.

Drake, N.A., Blench, R.M., Armitage, S.J., Bristow, C.S. and White, K.H. 2011. Ancient watercourses and biogeography of the Sahara explain the peopling of the desert. Proceedings of the National Academy of Sciences of America 108: 458-462.

Drake, N., Aouadi, N., Candy, I., Gasmi, N., Schwenninger, J-L., Peat, D., Belhouchet, L., Mekki, H., Stoetzel, E. and Barton, N. (forthcoming) Aterian occupation of a humid Sahara during MIS 5: evidence from shoreline deposits of a megalake in Southern Tunisia. Quaternary Science Reviews.

Duller, G.A.T. 2004. Luminescence dating of Quaternary sediments: recent advances. Journal of Quaternary Science 19: 183-192.

Fisher, J.W. 1995. Bone surface modifications in zooarchaeology. Journal of Archaeological Method and Theory 2: 7-68.

Freundlich, J.C., Kuper, R., Breunig, P. and Bertram, H.-G. 1989. Radiocarbon dating of ostrich eggshells. Radiocarbon 31: 1030-1034.

Geneste, J.-M. 1985. Analyse lithique d'industries moustériennes du Périgord: une approche technologique $d u$ comportement des groupes humains au Paléolithique moyen. Thèse de Doctorat, Université de Bordeaux I, France.

Geneste, J.-M. 1988. Les industries de la Grotte Vaufrey: technologie du débitage, économie et circulation de la matière première. In J.P. Rigaud (ed.) La Grotte Vaufrey: paléoenvironnement, chronologie, activités humaines. Mémoire de la Société Préhistorique Française 19: 441-517.

Gifford-Gonzalez, D. 1989. Ethnographic analogy for interpreting modified bones: some cases from east Africa. In R. Bonnichsen and M. Sorg (eds) Bone Modification. Institute for Quaternary Studies, University of Maine: 179-246.

Gobert, E.-G. 1962. La préhistoire littorale de la Tunisie. Quaternaria VI: 271-307.

Gobert, E.-G. and Howe, B. 1955. L'Ibéro-maurusien de l'Oued el Akarit (Tunisie). In L. Balout (ed.) Actes du IIème Congrès Panafricain de Préhistoire d'Alger 1952. Edita, Casablanca: 576-596.
Goldberg, P. and Macphail, R. I. 2012. Gorham's Cave sediment micromorphology. In R.N.E Barton, C.B. Stringer and J.C. Finlayson (eds) Neanderthals in Context. A Report of the 1995-1998 Excavations at Gorham's and Vanguard Caves, Gibraltar. Monograph 75: Oxford University School of Archaeology, Oxford: 50-61; Appendix 52: 314-321; Colour figures: www.arch.ox.ac.uk/gibraltar

Guerin, G., Mercier, N. and Adamiec, G. 2011. Dose-rate conversion factors. Ancient TL 29: 5-8.

Huntley, D.J., Godfrey-Smith, D.I. and Thewalt, M.L.W. 1985. Optical dating of sediments. Nature 313: 105-107.

Inizan, M.-L., Roche, H. and Tixier, J. 1992. Technology of Knapped Stone. Cercle de Recherches et d'Etudes Préhistoriques, CNRS, Meudon.

Isaac, G.L. 1983. (Review) Bones: Ancient Men and Modern Myths by Lewis R. Binford. American Antiquity 48: 416-419.

Johnson, E. 1985. Current developments in bone technology. In M.B. Schiffer (ed.) Advances in Archaeological Method and Theory. Academic Press, San Diego: 157-235.

Kandel, A.W. and Conard, N.J. 2005. Production sequences of ostrich eggshell beads and settlement dynamics in the Geelbek Dunes of the Western Cape, South Africa. Journal of Archaeological Science 32(12): 1711-1721.

Karkanas, K. and Goldberg, P. 2018. Reconstructing Archaeological Sites. Understanding the Geoarchaeological Matrix. Wiley Blackwell, Chichester.

Linderholm, J. 2007. Soil chemical surveying: a path to a deeper understanding of prehistoric sites and societies in Sweden. Geoarchaeology 22(4): 417-438.

Lyman, R.L. 1994. Vertebrate Taphonomy. Cambridge Manuals in Archaeology, Cambridge University Press, Cambridge.

Macphail, R.I. and Goldberg, P. 1999. The soil micromorphological investigation of Westbury Cave. In P. Andrews, J. Cook, A. Currant and C. Stringer (eds), Westbury Cave. The Natural History Museum Excavations 1976-1984. Centre for Human Evolutionary Research at the University of Bristol, Bristol: $59-86$.

Macphail, R.I., Goldberg, P. and Barton, R.N.E. 2012. Vanguard cave sediments and soil micromorphology. In R.N.E Barton, C.B. Stringer and J.C. Finlayson (eds), Neanderthals in Context. A Report of the 1995-1998 Excavations at Gorham's and Vanguard Caves, Gibraltar. Monograph 75, Oxford University School of Archaeology, Oxford: 193-210; colour figures available at: www.arch.ox.ac.uk/gibraltar

Macphail, R.I. and Goldberg, P. 2018. Applied Soils and Micromorphology in Archaeology. Cambridge University Press, Cambridge.

Mallol, C., Mentzer, S.M. and Miller, C.E. 2017. Combustion features. In C. Nicosia and G. Stoops (eds), Archaeological Soil and Sediment Micromorphology. Wiley, Chichester: 299-330.

Miller, J.M. and Willoughby, P.R., 2014. Radiometrically dated ostrich eggshell beads from the Middle and Later Stone Age of Magubike Rockshelter, southern Tanzania. Journal of Human Evolution 74: 118-22.

Mirazón Lahr, M., Rivera, F., Power, R.K., Mounier, A., Copsey, B., Crivellaro, F., Edung, J.E., Maillo Fernandez, J.M., Kiarie, C., Lawrence, J., Leakey, A., Mbua, E., Miller, H., Muigai, A., Mukhongo, D.M., Van Baelen, A., Wood, R., Schwenninger, J.-L., Grün, R., Achyuthan, H., Wilshaw, A. and Foley, R.A. 2016. Inter-group violence among early Holocene hunter-gatherers of West Turkana, Kenya. Nature 529: 394-398.

Nicosia, C. and Stoops, G. 2017. Archaeological Soil and Sediment Micromorphology. Wiley Blackwell, Chichester.

Noe-Nygaard, N. 1989. Man-made trace fossils on bones. Human Evolution 4(6): 461-491.

Orton, J., 2008. Later Stone Age ostrich eggshell bead manufacture in the northern Cape, South Africa. Journal of Archaeological Science 35(7): 1765-1775.

Page, W.D. 1972. The Geological Setting of the Archaeological Site at Oued El Akarit and the Palaeoclimatic Significance of Gypsum Soils, Southern Tunisia. Doctoral thesis, University of Colorado.

Rhodes, E.J. and Schwenninger, J.-L. 2007. Dose rates and radioisotope concentrations in the concrete calibration blocks at Oxford. Ancient TL 25: 5-8.

Roberts, P., Stewart, M, Alagaili, A.N., Breeze, P., Candy, I., Drake, N, Groucutt, H.S., Scerri, E.M., Throp, J.L., Louys, J., Zalmout, I., Al-Mufarreh, Y.S.A, Zech, J., Alsharekh, A.M, Al Omari, A., Boivin, N. and Petraglia, M. 2018. Fossil herbivore stable isotopes reveal middle Pleistocene hominin palaeoenvironment in 'Green Arabia'. Nature Ecology \& Evolution. https://doi.org/10.1038/s41559-018-0698-9

Roset, J.-P. and Harbi-Riahi, M. (eds), 2007. El Akarit: un site archéologique du Paléolithique moyen dans le Sud de la Tunisie. Editions Recherches sur les Civilisations, Paris. 
Stiner, M.C., Kuhn, S.L., Weiner, S. and Bar-Yosef, O. 1995. Differential burn ing, recrystallisation, and fragmentation of archaeological bone. Journal of Archaeological Science 22: 223-237.

Turney, C.S. 1998. Extraction of rhyolitic component of Vedde microtephra from minerogenic lake sediments. Journal of Paleolimnology 19(2): 199-206.
Viklund, K., Linderholm, J. and Macphail, R.I. 2013. Integrated palaeoenvironmental study: micro- and macro-fossil analysis and geoarchaeology (soil chemistry, magnetic susceptibility and micromorphology). In L.-E. Gerpe (ed.), E18-prosjektet Gulli-Langåker. Oppsummering og arkeometriske analyser, Volume Bind 3. Fagbokforlaget, Bergen: 25-83. 